\title{
The World Map \\ of the Corpus Pelagianum \\ (BNE, 1513, fol. 1v) \\ and its Strategies of Identification
}

\author{
Patrick S. Marschner*
}

One of the manuscripts of the famous Corpus Pelagianum contains a square world map that is simultaneously a genealogical chart of peoples that are descended from the sons of Noah. In combining a geographical imagination of the world with genealogies, this illustration becomes an impressive intellectual achievement of the high medieval Iberian Peninsula and differs considerably from other forms of medieval world maps. In this article the characteristics of this cartographical and genealogical figure will be investigated in general, but also with regard to the map's context in the manuscript Madrid, BNE, 1513. Hence, the map will be contextualised in relation to the text corpus that follows it and, therefore, its interaction with the textual heritage of Christian-Iberian historical writing, from the ninth to the twelfth centuries, will be illuminated. In particular, the Etymologies of Isidore of Seville were an important source, both for the textual content of this codex and for the information displayed on the map. Accordingly, this article is, after some introductory passages on the composition of the codex BNE 1513, divided into two parts. The first describes the characteristics of the geographical chart and compares them with other contemporary world maps. The second part addresses peoples of the world that appear in this illustration and discusses how their identification correlates with the historiographical texts in BNE 1513. So far, these parallels have not been taken into account in research on this codex.

Keywords: mappae mundi; genealogy; Christian-Muslim relations; Isidore of Seville; Pelayo of Oviedo; Corpus Pelagianum; BNE 1513; Chronicle of Alfonso III; Chronicle of Sampiro; Chronicon regum Legionensium; ethnonyms

* Correspondence details: Dr. Patrick S. Marschner, Institute for Medieval Research, Austrian Academy of Sciences, Hollandstraße 11-13, 1020 Vienna, Austria; email: Patrick.Marschner@oeaw.ac.at. 


\section{Introduction}

The manuscript 1513 of the Spanish National Library, also named "Códice de Batres", was written around 1200 in Oviedo ${ }^{2}$ and belongs to the famous Corpus Pelagianum. This manuscript is based on a compilation by Bishop Pelayo of Oviedo (died in 1153), whose main intention is to emphasise the role of his diocese. ${ }^{3}$

Beginning with a geographical scheme, a specific form of a mappa mundi, described in more detail below, the codex BNE 1513 differs in a significant respect from other manuscripts of the Corpus Pelagianum. ${ }^{4}$ No other Pelagian witness, especially not the two perhaps most comparable codices, BNE 1358 and 2805, offers this kind of illustration. ${ }^{5}$ Additionally, this map is not a map in pure form, as it also exhibits the qualities of a genealogical table, referring to the three sons of Noah and their descendants. Its schematic layout differs considerably from other forms of medieval mappae mundi.

1 Pérez de Urbel, Sampiro, 165; Galván Freile, MS. 1513, 479; Fernández Conde, Pelayo de Oviedo, 13. A completely digitised version of this codex is provided by the Spanish National Library, accessed on 21 April 2021: bdh-rd.bne. es/viewer.vm?id=0000005990\&page $=1$.

2 Fernández Conde, Pelayo de Oviedo, 13 and 14 n. 5; Galván Freile, Iconografía, ornamentación y valor, 234 n. 61 and Galván Freile, MS. 1513, 494-495 date it to the early years of the thirteenth century, but also take into account arguments for an emergence in the late twelfth century, which is also discussed by Sánchez Alonso, Crónica del obispo, 17-18 and Barton and Fletcher, World of el Cid, 71.

3 The Corpus Pelagianum contains in particular texts that substantiate the desired leadership role of the diocese of Oviedo. See Pérez de Urbel, Sampiro, 136-165; Fernández Conde, El Libro de los Testamentos, 50-61; Fletcher, Episcopate, 72-74. See generally on Bishop Pelayo and the Corpus Pelagianum, Alonso Álvarez, Corpus Pelagianum; Alonso Álvarez, Obra histórica; Alonso Álvarez, Obispo Pelayo; Jerez, Arte compilatoria pelagiana; Alonso Álvarez, Rey Alfonso VI, 16-19; de Toro Vial, Pelayo de Oviedo, 15.

4 Madrid, BNE, 1513, fol. 1v. There has been only a little investigation of this object so far. The studies in which one would expect to find it discussed, do not in fact address it. Destombes, Mappemondes does not refer to this map. In his study of miniatures and further illustrations of the codex 1513, Galván Freile, MS. 1513, 483-494 does not examine the map either. Also the extensive and versatile article of Woodward, Medieval Mappaemundi, does not relate to this map. Equally, Pinet, Task of the Cleric does not mention it. Most recently, the scheme has been investigated by de Toro Vial, Pelayo de Oviedo, 6-7 and 20, where he transcribed and translated it into Spanish, and Fernández Conde, Pelayo de Oviedo, 52-53.

5 Madrid, BNE, 1358 and Madrid, BNE, 2805. For more information on these manuscripts see Inventario general 4, 401-404 for the first and Inventario general 8, 365-367 for the second. In this article I define as an illustration every graphical depiction that is not or not entirely textual, which contains maps, diagrams, miniatures etc. 


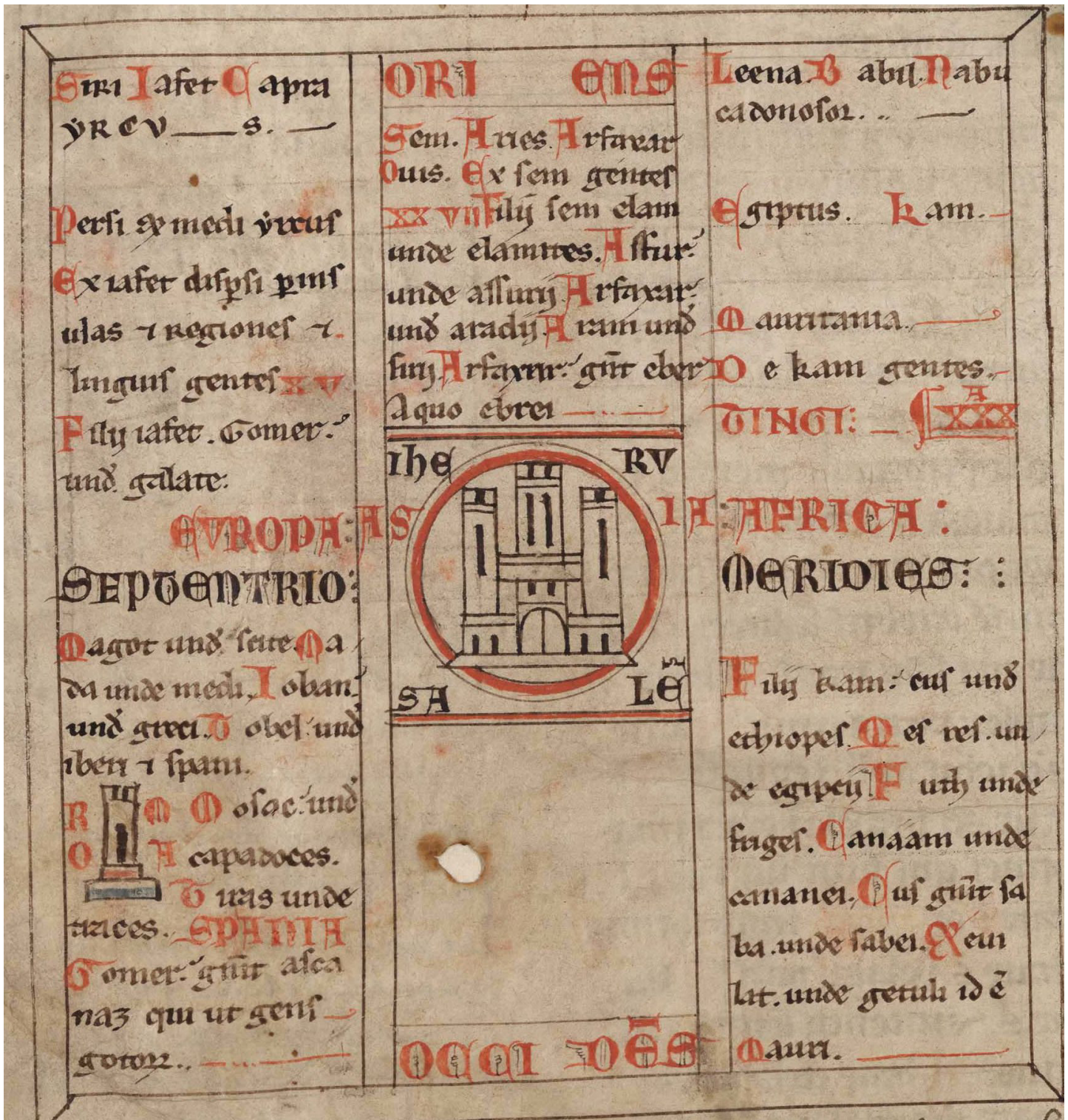

Figure 1: Geo-genealogical scheme. Madrid, BNE, MS. 1513, fol. 1 .

The map combines different ways of presenting knowledge, and the sources for this material will be discussed here. In particular, the genealogical content of this chart is closely related to the historiographical texts that follow in the codex BNE 1513. To what extent do the texts and the map interact directly, and to what extent can the similarities be explained by the fact that both use material from Isidore's Etymologies? To start with, an overview of this codex and its structure will be given. 


\section{The Composition of the Codex Madrid, BNE 1513}

BNE 1513 contains further illustrated geographical, or rather meteorological, elements, a diagram on consanguinity with respect to the degrees of kinship, historiographical texts, transcripts of royal decrees, various council documents, and two small historical texts, each addressing theories of time. ${ }^{6}$ In particular, the combination of historiographical texts following the geographical illustrations and descriptions represents a specific interaction of the depiction of history and space in this codex. ${ }^{7}$

The illustration on folio $1 \mathrm{v}$ is followed directly opposite the opening by another one, a diagram depicting consanguinities to six degrees, on fol. 2 r. $^{8}$ This symmetric diagram basically follows the form produced in Isidore's Etymologies. ${ }^{9}$ As Galván Freile mentioned, diagrams like this were not unusual in contemporary Hispania. ${ }^{10}$ Yet, it is difficult to explain its relationship to the preceding illustration. One could speculate that on fol. $1 \mathrm{v}$ relationships of peoples are depicted in a universal sense, whereas fol. $2 \mathrm{r}$ displays relationships on a lower level, namely between individuals. After a short text passage explaining the diagram of consanguinity, the next two illustrations within the codex, on fols $3 \mathrm{r}$ and $3 \mathrm{v}$, both comprise schemes of the different winds from the cardinal directions, ${ }^{11}$ which are also drawn from Isidorean knowledge; ${ }^{12}$ one gets the impression, therefore, that the main correlation uniting these illustrations in the first folios of the codex is their connection to Isidore's Etymologies. By collecting Isidorean knowledge, Pelayo of Oviedo may have sought to style himself as a scholar. ${ }^{13}$

6 Inventario general 4, 401-404. See also the website of the Biblioteca Nacional de España, accessed on 21 April 2021: bdh.bne.es/bnesearch/detalle/bdhoooooo5990\#. Galván Freile, MS. 1513, 482-483.

7 On the impossibility of investigating such an illustration in isolation from the surrounding text(s), see Müller, Visuelle Weltaneignung, 25-26.

8 Madrid, BNE, 1513, fol. 2r.

9 Galván Freile, MS. 1513, 483; Isidore of Seville, Etymologiarum, 9.5-6, ed. Lindsay.

10 Galván Freile, MS. 1513, 483 n. 20.

11 Madrid, BNE, 1513, fol. 3r., also depicted in Galván Freile, MS. 1513, after 496 [no pagination]; Madrid, BNE, 1513, fol. $3 \mathrm{v}$.

12 Galván Freile, MS. 1513, 484; Isidore of Seville, Etymologiarum, 13.11.2-3, ed. Lindsay. The illustration on fol. 3r. contains a possible error: the cardinal directions north and south in the inner circle are mixed up - the wind called "Septentrio« would blow from the south while the "Auster « would blow from the north, which, in truth, is the other way around in the medieval imagination. This has previously been mentioned by Galván Freile, MS. 1513, $484 \mathrm{n}$. 21. But there is the possibility that this depiction functions in a similar way as a planisphere from today's astronomy education. Such a planisphere also shows north and south interchanged as long as laid out in front of the observer. But if one holds it above the head, the depiction turned down, the cardinal directions are correct again. Since the illustration of winds from BNE 1513, fol. $3 \mathrm{r}$ from a certain point of view shows phenomena from the sky, there is a possibility that it might have been used or at least understood like that.

13 In both of the schemes in Madrid, BNE, 1513 fol. $3 \mathrm{r}$ and fol. $3 \mathrm{v}$ the following is written in the middle: »Pelagius episcopus me fecit. « On fol. 3v the ıfecit« is written out. Trans.: »I, Bishop Pelayo, made this«; All quotations from manuscript sources are transcribed diplomatically, but with spacing regularised and abbreviations expanded in italics. On the characteristics of Bishop Pelayo as a compiler or collector of knowledge, see the studies mentioned above in n. 3 . 
The presentation of history in BNE 1513 starts with texts on the creation and the aetates mundi. ${ }^{14}$ Unsurprisingly, some content from the initial scheme, such as on the descendants of Noah's son Shem, reappears in these passages of biblical stories. ${ }^{15}$ They offer a genealogy from Shem up to Ishmael and the Ishmaelites and also to the Israelites in a textual manner, i.e. without any graphical support. It makes obvious reference to the Table of Nations. ${ }^{16}$ After giving a brief history of the people of Israel, touching, for instance, on the stories of Moses or David, the historical focus then turns to the Roman Empire under Octavian, mentioning the birth of Jesus, ${ }^{17}$ and continues with the depiction of the Roman emperors up until Tiberius III (698-705) ${ }^{18}$ Having reached the contemporaries of the last Visigothic kings, the compilation does not, however, go further with the historiographical texts of the Iberian Peninsula. Instead, the historical narration gets interrupted by the biblical stories of Job, Joseph, Moses, and the rulers of the people of Israel until Solomon. ${ }^{19}$ These passages are followed by Jerome's exegesis of the book of Ezekiel and further biblical genealogies. ${ }^{20}$ After a short depiction of Jesus, Peter and Paul, as well as some accounts of persecutions against the Christians, the historical narration then leads to Gaiseric. ${ }^{21}$ Following that, the manuscript offers a computation of the years of the world. ${ }^{22}$

After these undoubtedly universal-historical elements, the codex contains continuous Hispanic chronicles, beginning with Isidore's Historia de regibus Gothorum, Vandalorum et Suevorum, ${ }^{23}$ followed by "Redaction C « of the Chronicle of Alfonso III, ${ }^{24}$ the Chronicle of Sampiro ${ }^{25}$ and Pelayo's Chronicon regum Legionensium. ${ }^{26}$ After these Christian-Iberian texts, the codex contains a version of the Liber historiae Francorum. ${ }^{27}$ Hence, the geographical depictions, the imagination of space and phenomena within space - such as the winds - are directly followed by history. In that manner, history and space are entangled in codex 1513 . Additionally, since the first and most prominent geographical depiction also contains genealogical elements that correlate with the content of the above-mentioned text about the

Madrid, BNE, 1513, fols. 4r-24r. Fernández Conde, Pelayo de Oviedo, 54-56,

For instance, Madrid, BNE, 1513, fol. 5r, right column: "Sem anno II' post diluvium cum esset C duo annorum genuit arfaxar a quo gens chaldeorum exhorta est«. Trans.: »In the second year after the Flood Sem, with one hundred and two years, begot Arpachshad from whom sprung up the people of the Chaldeans."

16 Genesis 10. All references to and quotations from the Bible are taken from the Vulgate. All English Bible translations are taken from the Douay-Rheims Bible.

17 Madrid, BNE, 1513, fol. 11r.

18 Madrid, BNE, 1513, fol. 18r.

19 Madrid, BNE, 1513, fol. 21r.

20 Madrid, BNE, 1513, fol. 21v-22r.

21 Madrid, BNE, 1513, fol. 22r-23r.

22 Madrid, BNE, 1513, fol. 23r-24r.

23 Madrid, BNE, 1513, fols. 24r-38r. Isidore of Seville, Historia Gothorum, ed. Mommsen, 295-303. The order of the parts of the text in the manuscript varies from the order in the edition.

24 Madrid, BNE, 1513, fols. 38v-52v. Redactio C, ed. Prelog, 70-129.

25 Madrid, BNE, 1513, fols. 52v-64r. Obviously, this is the »Pelagian version« of this chronicle. Sampiro of Astorga, Chronica, ed. Pérez de Urbel, 275-346, left column.

26 Madrid, BNE, 1513, fols. 64r-72v; Chronicon regum Legionensium, ed. Fernández Conde, 28-37.

27 Madrid, BNE, 1513, fols.72v-101v. Apparently, it is version B according to the studies of Krusch, Fredegarii et aliorum chronica, $215-238$. 
aetates mundi and at least three of the chronicles, this map interacts with the historical writing in the codex. Due to the constructions of identity that can be found in both the map and the historiographical texts, the field of historical identification will be the most important element of this comparison.

The chronicles of Isidore, Alfonso III, Sampiro and Pelayo are also related to each other through their contents. Beginning with the reign of Wamba, the Chronicle of Alfonso III relates to the content of the Historia Wambae regis of Julian of Toledo, ${ }^{28}$ but is also tied to Isidore's Historia de regibus Gothorum, Vandalorum et Suevorum, since it is in some points a continuation of the latter. ${ }^{29}$ While the Chronicle of Alfonso III connects to the last Visigothic chronicles, the eleventh-century Chronicle of Sampiro begins with precisely that part of Iberian history that the Chronicle of Alfonso III ended with: the reign of Alfonso III. ${ }^{30}$ In the same way, the Chronicon regum Legionensium is a continuation of the Chronicle of Sampiro. ${ }^{31}$ Accordingly, the Hispanic historiographical texts in BNE 1513 seem to mirror continuity from the last Visigothic kings until the days of Bishop Pelayo of Oviedo. ${ }^{32}$ This "grand narrative ${ }^{33}$ contains an intense examination of the cultural and religious "Other" in the Iberian Peninsula, the Arab foreign rulers, from the Chronicle of Alfonso III until the Chronicon regum Legionensium. As will be shown below, the initial scheme on fol. 1v correlates with the depiction of the "Other " in these historiographical texts. Therefore, the scheme should also be understood through the historiographical approach.

Bearing all this in mind, the composition of BNE 1513 taken as a whole can be interpreted as depiction of the compilers ideas of both space and history. Both components that shape this codex are of a universal character: the geographical and meteorological elements refer to all parts of the (known) world, while the history that is written in BNE 1513 begins with creation, historically thematises several regions of the world, describes the aetates mundi, and turns the focus of this universal history to the post-conquest Christian realms in the north of Hispania. This codex grasps the world in its entirety, concerning both history and space. In doing so, it converges with the almost all-embracing knowledge of Isidore's Etymologies, which form a significant and striking component of this manuscript. Ultimately, Bishop Pelayo of Oviedo, the compiler of this collection of knowledge, is placed in direct succession to Isidore, as the most important bishops - as they appear in the aforementioned chronicles as authors or protagonists - are all depicted in the form of miniatures in this codex: Isidore, ${ }^{34}$ Julian of Toledo, ${ }^{35}$ the perhaps fictive

28 Historia Wambae regis, ed. Levison, 213-255; Redactio C, ed. Prelog, 70-71, for instance, contains several passages and information taken from the Historia Wambae regis. They are identified and further interpreted in Prelog, Chronik Alfons' III., 133-137 n.13-25.

29 Bronisch, Reconquista und Heiliger Krieg, 126.

30 Casariego [Fernández-Noriega], Crónicas de los Reinos, 79; Bronisch, Reconquista und Heiliger Krieg, 159.

31 Sánchez Alonso, Crónica del obispo, 43-44; Casariego [Fernández-Noriega], Crónicas de los Reinos, 161.

32 For example, on this topic, see Jerez, Arte compilatoria pelagiana, 66-87; Fletcher, Episcopate, 72-73.

33 Concerning the justified criticism of this term as it was used in nationalistic Spanish depictions of medieval Iberian history from the middle of the twentieth century, see Payne, Visigoths and Asturians reinterpreted, 48, 51-54.

34 Madrid, BNE, 1513, fol. 28v.

35 Madrid, BNE, 1513, fol. 38v.

medieval worlds $\bullet$ No. $13 \cdot 2021 \cdot 195-228$ 
Sebastian, ${ }^{36}$ Sampiro of Astorga, ${ }^{37}$ and finally, Pelayo of Oviedo. ${ }^{38}$ All of them also appear in succession in a small text passage towards the start of the codex. ${ }^{39}$ Perhaps Pelayo of Oviedo wanted to be understood as a new Isidore, reassembling the latter's wide-ranging knowledge. In the following, more traces of Isidore in Pelayo's work will be explored.

The »Geo-genealogical Scheme", its Peculiarities, and its Sources of Knowledge

The display on BNE 1513, fol. $1 \mathrm{v}$ is named "Divisio hominum in terrae regionibus" (division of the humans in the regions of the world) in the Inventario general of the Spanish National Library, ${ }^{40}$ even though this title does not appear in the manuscript. There is no individual denomination for this illustration. One of the latest investigators of this object, José Miguel de Toro Vial, calls it a "Tabla con el reparto del mundo entre los patriarcas" (table with the division of the world among the patriarchs). ${ }^{41}$ At the same time, de Toro Vial is aware of the cartographic character of this scheme. ${ }^{42}$ Francisco Javier Fernández Conde calls it a "Cosmovisión " (worldview) in his latest monograph. ${ }^{43}$ Indeed, the illustration on BNE 1513 , fol. $1 \mathrm{v}$ is a map, but it is more than that: it is also a table, a diagram, and a genealogy. Hence, in combining these forms it has been described as a "geo-genealogical scheme«. ${ }^{44}$ The genealogies basically follow Isidore's Etymologies, which are, again, based on the book of Genesis. ${ }^{45}$

In the following I am going to approach this scheme in four ways, which, however, cannot be strictly divided but rather merge into each other. In doing so, the somehow unique character of this scheme and, therefore, its differentiation from other more usual forms of medieval world maps will become clear. This discussion will reveal both its author's ability to combine different forms of knowledge into a complex world view, and the attempt to render this complexity in simple forms and compressed information. It will also cast light on the author's strategies of structuring knowledge.

36 Madrid, BNE, 1513, fol. 43r. On the presumable fictive nature of this bishop see Gil, Chronica Hispana, 112-116.

37 Madrid, BNE, 1513, fol. 48v.

38 Madrid, BNE, 1513, fol. 64v.

39 Madrid, BNE, 1513, fol. 4r; Gil, Chronica Hispana, 112.

40 Inventario general 4, 401.

41 de Toro Vial, Pelayo de Oviedo, 5-6.

42 de Toro Vial, Pelayo de Oviedo, 6.

43 Fernández Conde, Pelayo de Oviedo, 91. Also on p. 52 n. 12 Fernández Conde calls it a "Descripción del mundo« (description of the world) and assumes Bishop Pelayo himself being the originator of this map based on the questionable argumentation that the depictions of the winds, following this map, contain the aforementioned sentence that Pelayo created them. See above n. 13.

44 I would like to thank Prof. Dr. Uta Heil (pers. comm., 19 June 2020) for this phrasing, which she suggested during a webinar in which I presented an earlier version of this research.

45 de Toro Vial, Pelayo de Oviedo, 6; Isidore of Seville, Etymologiarum, 9.2.2-5, 10-14, 27, 29, 89, ed. Lindsay; Genesis 10. 


\section{The Scheme as a Map}

The characteristics that mark this scheme as a map ${ }^{46}$ in a contemporary and geographical sense are several: defining the cardinal directions is one. Depicting the world with the eastern direction on top is completely usual in medieval maps, partly due to the sun rising in the east and partly through locating Paradise in this direction (which very likely coincides). ${ }^{47}$ Second, the trichotomy of this scheme is a typical element of medieval world maps, which show the three inhabited parts of the (empirically known) world, the ecumene, divided into Europe, Asia and Africa and allocated to the sons of Noah. ${ }^{48}$ Usually, Asia is depicted as the biggest part of the world - a point on which this map definitely differs greatly from broader medieval traditions. In the common T-O maps, Asia occupies about fifty percent of the orbis terrae, while Europe and Africa share the remaining space. ${ }^{49}$ The reason for Asia having only a very small area in comparison to Europe or Africa in the map of the Corpus Pelagianum can only be speculated upon: was the size of Asia less important for the author of the map and, therefore, the dimensions shrunk in favour of Jerusalem, which has a dominant position and occupies about one ninth of the map? Was the geographical information of the size of continents less important than the genealogies that relate to each part of the ecumene for the author of this map, and if so, why in particular should the genealogy of Shem's descendants be the smallest (but most closely packed)? Do these questions perhaps correlate? Does the empty area to the west of Jerusalem represent the Mediterranean $\mathrm{Sea}^{50}$ or has the genealogy of the Semites simply not been finished and should it have instead been continued down into this field? In what other way could this blank space, which is usually avoided in medieval maps, ${ }^{51}$ be justified?

The form of such a map may result from both a rethinking of the order of the world and a construction of specific knowledge, e.g. political, religious or social. ${ }^{52}$ Hence, cartography can be a language in a semiotic sense, cultural symbolism, and a social product supporting control over spaces and facilitating the expansion of social systems. ${ }^{53}$ Therefore, a map is a result of influences coming from contemporary imaginations, purposes of depiction, and the combination of knowledge.$^{54}$ Consequently, Christian high-medieval world maps have to be

46 Generally, there is no clear definition of what a map is, neither in a contemporary sense nor given by today's cartographical or geographical science. What defines a map is foremost what it expresses. What is common to all maps is that they reduce information for the sake of easier understanding of spatial circumstances. Witt, Lexikon der Kartographie, 301.

47 Simek, Erde und Kosmos, 59. Edson et al., Mittelalterliche Kosmos, 55; Edson and Savage-Smith, Medieval Views, 58; Podossinov, Orientierung der alten Karten, 36; von den Brincken, Mundus figura rotunda, 100; Fernández Conde, Pelayo de Oviedo, 52.

48 Woodward, Medieval Mappaemundi, 296; Edson and Savage-Smith, Medieval Views, 50; Harvey, Mappa mundi, 21; Gautier-Dalché, Héritage Antique, 56; Weeda, Ethnic identification and stereotypes, 588. Concerning the reasons of the trichotomy in Genesis 10 see Hieke, Völkertafel, 27-28, 30, and especially 32; Pinet, Task of the Cleric, 27; Fernández Conde, Pelayo de Oviedo, 52.

49 A brief overview is given in Mauntel et al., Mapping continents, 310-312.

50 Mauntel et al., Mapping continents, 329; Fernández Conde, Pelayo de Oviedo, 53.

51 von den Brincken, Ausbildung konventioneller Zeichen, 341-342; Mauntel et al., Mapping continents, 341.

52 Baumgärtner, Welt im kartographischen Blick, 527-528.

53 Harley, Maps, knowledge, and power, 278-279, 304-305; I came across these definitions through Baumgärtner, Welt im kartographischen Blick, 528, referring to Harley, who himself built his definitions in part based on those of Aby Warburg and Michel Foucault.

54 Baumgärtner, Welt im kartographischen Blick, 528. 
seen as a particular image of the world rather than as a realistic display. ${ }^{55}$ In the case of BNE 1513 , fol. $1 \mathrm{v}$, it is - as we will discover below - a depiction of the world's peoples affecting Iberian history, created by a Christian intellectual, who was aware of the transcultural situation in the Peninsula and the foreign rulers dominating major parts of the region.

The divergent proportions between the parts of the world and the square shape of this map are the characteristics that make it somehow unique. Contemporary maps mostly have only round, oval or at least rounded forms..$^{56}$ That being said, there are several comparable geographical depictions in contemporary manuscripts, especially as graphical additions to Isidore's Etymologies, that are also square instead of round. For instance, a twelfth-century manuscript of Isidore's Etymologies from Göttweig, now held in the Austrian National Library in Vienna, offers a square scheme, divided into three triangles, each dedicated to one son of Noah. ${ }^{57}$ This $" V$-in-square map ${ }^{58}$ is accompanied by at least three of the cardinal directions with east on top and, is therefore, from a certain perspective, similar to BNE 1513, fol. 1v.

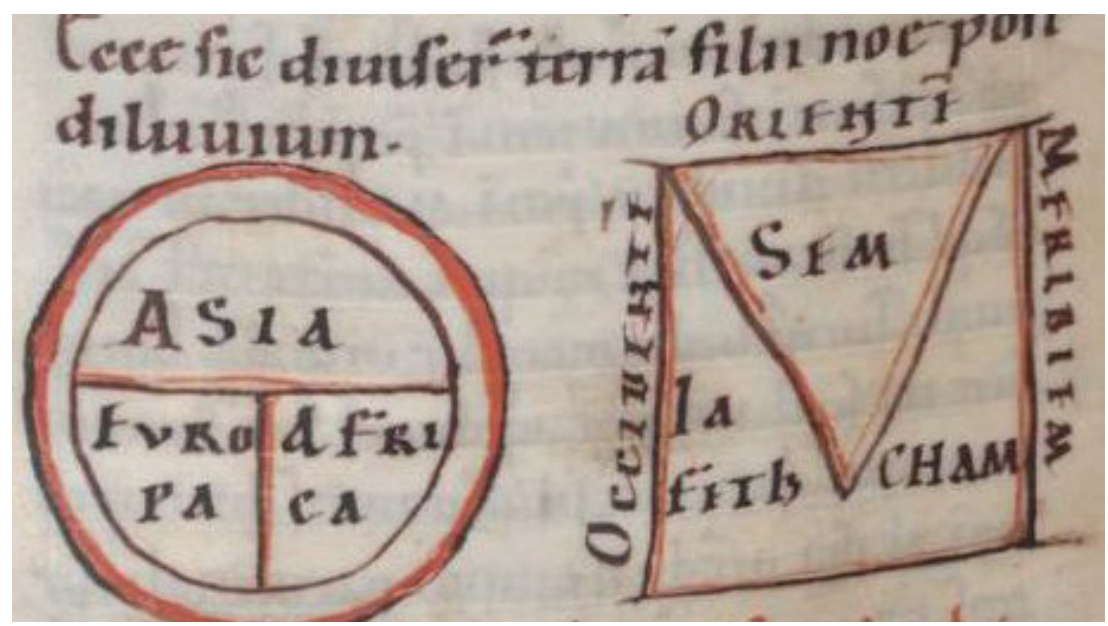

Figure 2: T-O map and V-in- $\square$ map in a copy of Isidore's Etymologies. Vienna, Österreichische Nationalbibliothek, Cod. 67, fol. 117v.

The proportions of the spaces assigned to each of Noah's sons in this map on Vienna, Cod. 67, fol. $117 \mathrm{v}$ are almost even. Furthermore, it is positioned adjacent to a simple T-O map. Very similar V-in-square maps - with assignments of each of the equal parts to one of Noah's sons, cardinal directions, orientation towards the east ${ }^{59}$ or even accompanied by T-O maps - can be found in many regions of medieval Europe - including the Iberian Peninsula - from at

55 von den Brincken, Mappa mundi, 122.

56 von den Brincken, Mundus figura rotunda, 99-103.

57 Vienna, ÖNB, Cod. 67, fol. 117v.

58 Van Duzer, Neglected type, 278. To emphasise the shape of these maps, Van Duzer also offers the spelling »V-in- $\square$ map«.

59 This is somewhat tautological, since the term "orientation" originates from "oriens «, east. A different definition is given by von den Brincken, Mappa mundi, 175, ascribing the term to the Italian language as a reference to the setting of sails against the wind. For the characteristics of V-in-square maps in general, see Van Duzer, Neglected type, 278. 
least the ninth to the fifteenth centuries. In most cases, they appear as additions to copies of Isidore's Etymologies ${ }^{60} \mathrm{~A}$ decidedly Iberian example of such a V-in-square map appears in an eleventh-century copy of Beatus of Liébana's Commentary on the Apocalypse, also embedded in an Old Testament genealogy. ${ }^{61}$

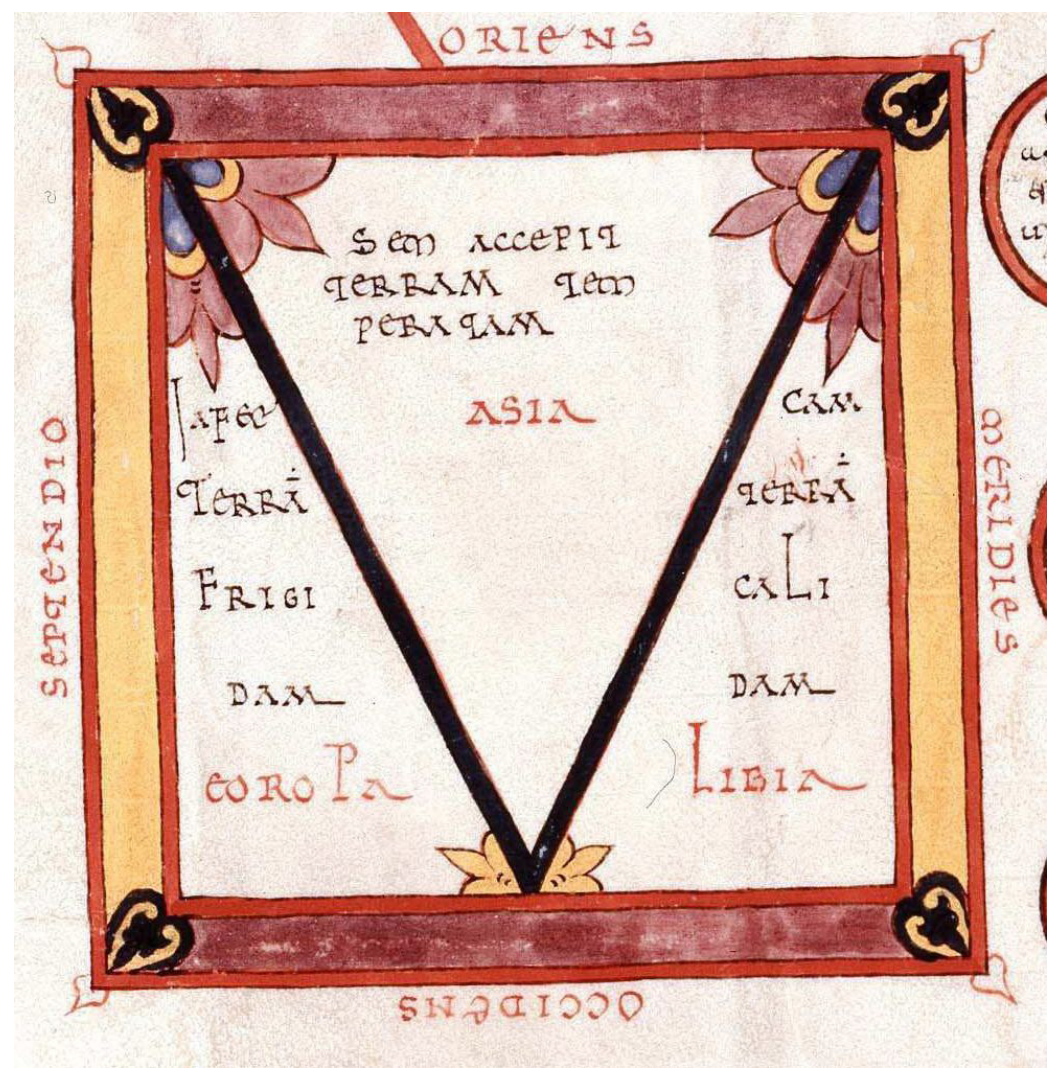

Figure 3: V-in- $\square$ map in a copy of Beatus of Liébana's Commentary on the Apocalypse. Madrid, BNE, Vitr. 14-2, fol. $12 v$.

BNE, Vitr. 14-2, where we find the above illustration, contains another world map of some size, positioned across the opening of two folios (fols $62 \mathrm{v}-63 \mathrm{r}$ ); it follows the T-O scheme but is somewhat rectangular rather than round. Jerusalem is not positioned in the centre but is instead very exposed near the midpoint, the map is orientated towards the east and contains several topographical terms such as Rome, Tarragona, Pannonia or »Mauritania Tingitania ${ }^{62}$

60 Woodward, Medieval Mappaemundi, 301; Van Duzer, Neglected type, 278-280, for illustrations, see especially 293-296.

61 Madrid, BNE, Virt. 14-2, fol. 12v.

62 Madrid, BNE, Virt. 14-2, fols 62v-63r. This map and its potential tenth-century predecessor are thematised briefly in Baumgärtner, Welt im kartographischen Blick, 531-534. 


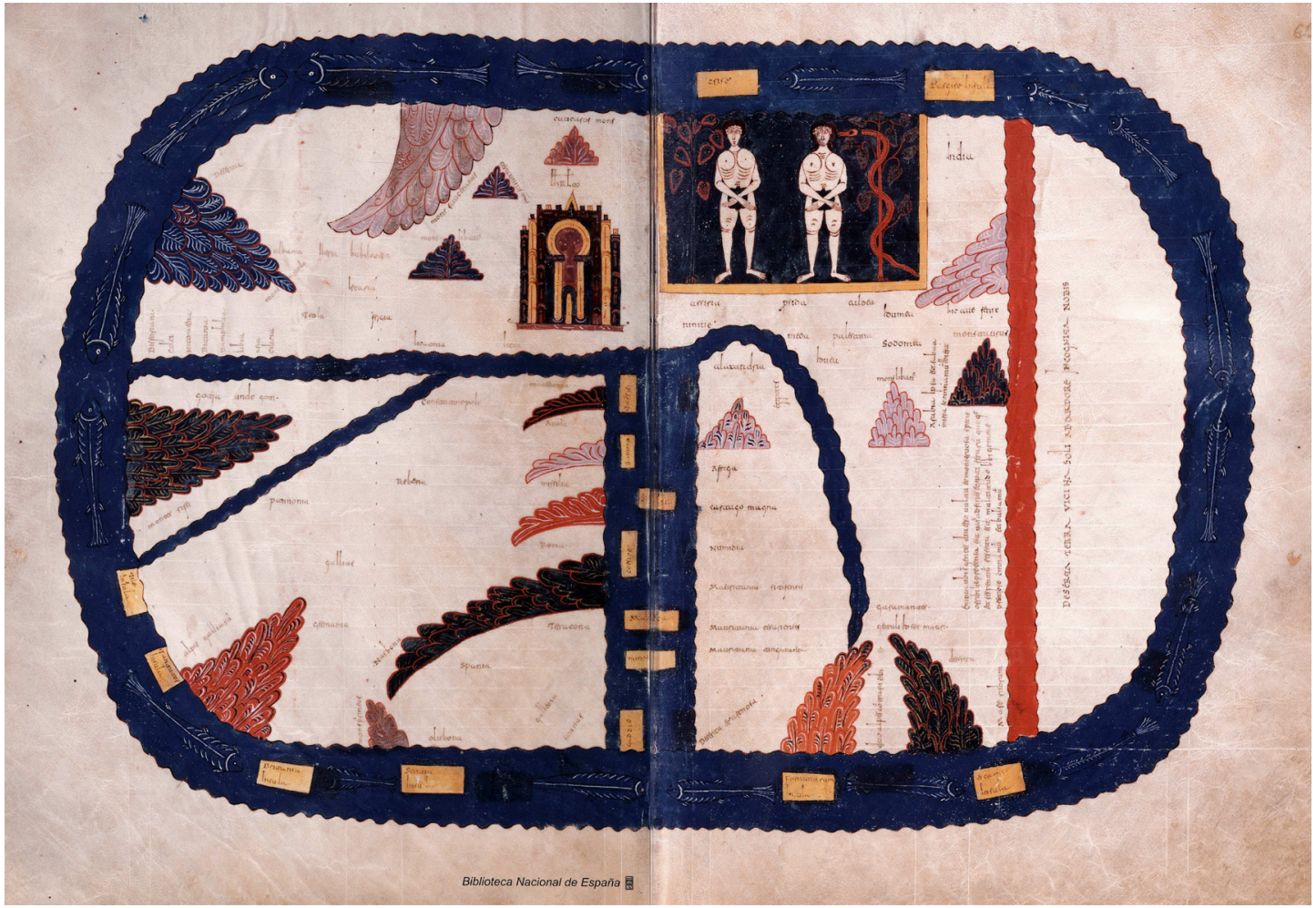

Figure $4(a-b)$ : World map in a copy of Beatus of Liébana's Commentary on the Apocalypse. Madrid, BNE, Vitr. 14-2, fols 62v-63r.

One could speculate that the author of the Pelagian scheme was aware of both types of mappae mundi and, thus, mixed them. In all probability, there was a Beatus codex in Oviedo, containing comparable illustrations of the corresponding maps. ${ }^{63}$

Apart from the unusual dimensions of Asia and the unclear role of the empty area to the west of Jerusalem, the map of the Corpus Pelagianum seems to follow the schematic approach of the V-in-square maps rather than that of T-O maps, albeit elements like the central position of Jerusalem or the depiction of Rome are striking differences. The connection to Isidorean knowledge especially supports this assessment. At the least, one could interpret the two lines of the typical $\mathrm{V}$ as simply being paralleled for the sake of a more practical layout for writing in the resulting columns.

63 Miller, Weltkarte des Beatus, 21. 
Returning from the mere geometric form of BNE 1513, fol. $1 \mathrm{v}$ to its content, the positioning of Jerusalem in the centre of the known world is a usual element of medieval mappae mundi, especially of the T-O type. As the place where Jesus' grave is located and where the Easter event, the beginning of salvation, took place, Jerusalem was interpreted as the navel, the centre of the world in both the spatial and the historical sense. ${ }^{64}$ Furthermore, it could also have drawn on a passage from the book of Ezekiel that reasoned the geographical position of Jerusalem in the centre of the world. ${ }^{65}$

Finally, the four cardinal directions and several topographic terms in the scheme are an unequivocal sign of a map. First, there are the names of the three known parts of the world located in each third and written in red capitals: »Europa «, "Asia« and "Africa«. In the centre of the map, Jerusalem is the only toponym belonging to Asia. "Mauritania « and "Tingi« are the only two terms describing a region and a city ${ }^{66}$ in Africa. Lastly, in the area of Europe, Rome and Hispania are the only toponyms given. ${ }^{67}$ Thus, on every continent at least one name of a city appears: Rome, Jerusalem, and Tingi. The character in which "Mauritania" is written in the upper third of the column representing Africa seems to be an exception, since "Roma«, "Spania«, »Europa«, »Asia«, »Africa«, and »Tingi« are written in red capitals and "Iherusalem" also at least in capitals. All other remaining text in this scheme, except the cardinal directions, is of the genealogical kind. Additionally, Rome and Jerusalem are the only cities which are both named and depicted with buildings in the map. This emphasising of these two cities is not surprising, since Jerusalem was, as mentioned above, understood as the navel of the world and Rome represented both the caput mundi as well as the sixth and final age of the world. From a Christian author's point of view, then, these are the two most important cities of the world's history. In a historiographical sense, Jerusalem could be understood as the turning point, the place where David and Solomon installed a divine kingship and built the first temple and also the place where Christ died and was resurrected and, in doing so, opened the way to the salvation of humankind, whereas Rome represents the final age. Interpreted like this, both are symbols related to salvation and, thus, more than mere places on earth.$^{68}$ Furthermore, most of the text referring to peoples and their origin in the map leads to the conclusion that the primary aim was the depiction of humankind, rather than offering a display of the physical world.

64 von den Brincken, Mappa mundi, 173; Simek, Erde und Kosmos, 95-96, 104; Wolf, Jerusalem und Rom, 208-220; Fernández Conde, Pelayo de Oviedo, 52.

65 Ezekiel 5, 5: "haec dicit Dominus Deus ista est Hierusalem in medio gentium posui eam et in circuitu eius terras". Trans.: "Thus saith the Lord God: This is Jerusalem, I have set her in the midst of the nations, and the countries round about her «; Baumgärtner, Wahrnehmung Jerusalems, 272, 275, who also refers to Jerome's influence on this image of Jerusalem.

66 Isidore of Seville, Etymologiarum, 14.4.12 and 15.1.74, ed. Lindsay.

67 de Toro Vial, Pelayo de Oviedo, 6; Fernández Conde, Pelayo de Oviedo, 52-53.

68 Goetz, Gott und die Welt, 160, 162-163, 216; Wolf, Jerusalem und Rom, 174-186, 188-206.

medieval worlds $\bullet$ No. $13 \cdot 2021 \cdot 195-228$ 


\section{The Scheme as a Table}

From another perspective, this geo-genealogical scheme could be interpreted as a table. ${ }^{69}$ Even though it lacks an arrangement into rows, the division into columns is obvious. Yet, it seems that the columns do not contain a clear and exclusive subject. If the columns were solely dedicated to Noah's sons in the order Japheth, Shem and Cham from left to right, then the cardinal directions, the depictions of cities and the denomination of the parts of the world would be alien elements - at least from today's perspective and with our definition of "table « in mind. On the other hand, the contemporaries' clear allocation of the continents to Noah's sons did not even admit the option for the author to categorise the terminology in the scheme into "geographical« and "genealogical«. Hence, to him there was no alien element but only an order of peoples in specific parts of the world. Thus, for the author, these columns could very well have had a clear and specific subject.

Furthermore, the genealogical content in each column is strictly delimited from the rest, and possible cross connections - which do exist in the Old Testament genealogies, as we will discover below - are absent. Accordingly, the three parts of the world function as columns of a table, especially as regards its genealogical content.

\section{The Scheme as Genealogy}

Genealogy is a way of depicting history, since its content enters the past alongside the ancestry of persons or peoples clarifying their origins. ${ }^{70}$ If such genealogies go back to the origin of all peoples, namely the biblical progenitors, as is the case in BNE 1513, fol. 1v, then this form of history becomes a universal one. ${ }^{71}$ Therefore, this map is not just a depiction of the entire inhabited world but also of the origin and history of its inhabitants. Admittedly, the genealogical story does not go back as far as the Creation, but instead to the end of the Flood, which is something of a second beginning of mankind's history. The story of Noah and his sons is a myth explaining the roots of all humans from that point in time, when mankind was virtually recreated. ${ }^{72}$ Therefore, the scheme's basis can not only be found in Isidore's Etymologies but also in Genesis 10, better known as the Table of Nations. This archetype of "Völkergenealogie « already intended to create a spatial order of the world,$^{73}$ and this function was passed on by Isidore ${ }^{74}$ and, moreover, by those medieval scholars, who built further upon his work.

69 de Toro Vial, Pelayo de Oviedo, 5-6.

70 Hieke, Genealogy, 391.

71 von den Brincken, Mappa mundi, 124: "Sind [...] mittelalterliche Weltkarten weitgehend gewissermaßen graphische Darstellungen der Weltchroniken, des Weltverlaufs im Raume, aufgezeichnet auf einer begrenzten Fläche, so sei es gestattet, sie [...] einmal nicht vom Standpunkt der Geographie, sondern von dem der Universalhistoriographie zu betrachten. Geschichtsschreibung stellt Menschen in Raum und Zeit dar, Universalgeschichtsschreibung sucht die Menschheit in der Gesamtheit des Raumes und der Summe der Zeit zu erfassen.« Trans.: »If medieval world maps are largely quasi graphic depictions of world chronicles, of the course of the world inside space, recorded in a limited range, it is permitted to contemplate them for once not from the perspective of geography but that of universal historical writing. Historical writing depicts humans in space and time, while universal history tries to conceive of mankind in the entirety of space and in the summa of time."

72 Hieke, Völkertafel, 24-25.

73 Hieke, Völkertafel, 24 and 30-31, concerning the uniqueness of the Table of Nations among religious texts of the antique Middle East and in comparison to ancient Greek genealogies.

74 Merrills, Geography and memory, 51. 
In one of her older studies, Anna-Dorothee von den Brincken did not take into account that genealogies can be a part of universal history ${ }^{75}$ although she identified the genre of encyclopaedic historical writing as such, among which she numbered Isidore's Etymologies.$^{76}$ Additionally, she reminds the reader of the continuing connection made between encyclopaedic universal chronicles and maps in medieval manuscripts. In particular, the allocation of the world's parts to Noah's sons has often been a cause of geographical excurses, presumably reasoned for the emergence of diversity out of unity. ${ }^{77}$ The scheme of BNE 1513 seems to be just such a case. An opening element of this manuscript comprises an Isidorean-encyclopaedic prologue to Iberian history, with the genealogies as they appear in the scheme being, essentially, taken from the ninth book of his Etymologies ${ }^{78}$ In the area - or column - of Europe, the descendants of Japheth are listed up until the people of the Goths, following Isidore's text with only minor variations:

\begin{tabular}{|c|c|}
\hline Madrid, BNE, 1513, fol. 1v & $\begin{array}{l}\text { Isidore, Etymologiarum 9.2.26-32, ed. } \\
\text { Lindsay }\end{array}$ \\
\hline $\begin{array}{l}\text { "Siri, Iafet, Capra| yreus | Persi et medi, yi- } \\
\text { rus | Ex iafet dispersi per ins|ulas et regiones } \\
\text { et | linguis gentes XV | Filii iafet. Gomerus | } \\
\text { unde galate | Magot [sic!] unde scite. Ma|da } \\
\text { unde medi. Iobanus | unde greci. Tobel unde } \\
\text { | iberi et spani | Mosacus unde | capadoces | } \\
\text { Tiras unde | traces | Gomerus genuit asca|naz } \\
\text { qui ut gens | gotorum« }\end{array}$ & $\begin{array}{l}\text { „Filii igitur Iaphet septem nominantur : Go- } \\
\text { mer, ex quo Galatae, id est Galli. Magog, a quo } \\
\text { arbitrantur Scythas et Gothos traxisse origi- } \\
\text { nem. Madai, a quo Medos existere putant. Ia- } \\
\text { van, a quo Iones, qui et Graeci. Vnde et mare } \\
\text { Ionium. Thubal, a quo Iberi, qui et Hispani; } \\
\text { Jicet quidam ex eo et Italos suspicentur. Mo- } \\
\text { soch, ex quo Cappadoces. Vnde et urbs apud } \\
\text { eos usque hodie Mazaca dicitur. Thiras, ex } \\
\text { quo Thraces; quorum non satis inmutatum } \\
\text { vocabulum est, quasi Tiraces. Filii Gomer, } \\
\text { nepotes Iaphet. Aschanaz, a quo Sarmatae, } \\
\text { quos Graeci Rheginos vocant." }\end{array}$ \\
\hline
\end{tabular}




\begin{tabular}{|c|c|}
\hline $\begin{array}{l}\text { Syrians, Japheth, Capra [?], Yrius [?]; Persi- } \\
\text { ans and Medes, Yirus; From Japheth spread } \\
\text { fifteen languages and peoples to the isles } \\
\text { and regions; Sons of Japheth. Gomer, from } \\
\text { whom [descent] the Galatians; Magot, from } \\
\text { whom [descent] the Scyths; Madai, from } \\
\text { whom [descent] the Medes; Javan, from } \\
\text { whom [descent] the Greeks; Tubal, from } \\
\text { whom [descent] the Iberians and Spani- } \\
\text { ards; Mosac, from whom [descent] the Ca- } \\
\text { padocians; Tiresias, from whom [descent] } \\
\text { the Thracians. Gomer begat Ashkenaz, from } \\
\text { whom [descent] the people of the Goths. }{ }^{79}\end{array}$ & $\begin{array}{l}\text { Seven sons of Japheth are named: Gomer, } \\
\text { from whom sprang the Galatians, that is, the } \\
\text { Gauls (Galli). Magog, from whom people think } \\
\text { the Scythians and the Goths took their origin. } \\
\text { Madai, from whom people reckon the Medes } \\
\text { came to be. Javan, from whom the Ionians, who } \\
\text { are also the Greeks - hence the "Ionian « Sea. } \\
\text { Tubal, from whom came the Iberians, who are } \\
\text { also the Spaniards, although some think the } \\
\text { Italians also sprang from him. Meshech, from } \\
\text { whom came the Cappadocians; hence to this } \\
\text { day a city in their territory is called Mazaca. } \\
\text { Tiras, from whom the Thracians; their name is } \\
\text { not much altered, as if it were Tiracians. Then } \\
\text { the sons of Gomer, the grandsons of Japheth. } \\
\text { Ashkenaz, from whom descended the Sarmati- } \\
\text { ans, whom the Greeks call Rheginians. }\end{array}$ \\
\hline
\end{tabular}

79 Madrid, BNE, 1513, fol. 1v. I left out the toponyms and cardinal direction listed in this space of the illustration. Concerning the reading of the manuscript, compare de Toro Vial, Pelayo de Oviedo, 20 and, partially, Fernández Conde, Pelayo de Oviedo, 53 n. 14.

80 Isidore of Seville, Etymologiarum, 9.2.26-32, ed. Lindsay; trans. Barney et al., Etymologies, 193. On the background of the story of Tubal, its underlying form in Isidore's Etymologies and its appearance in the thirteenth century, see Díaz [Martínez], Mito godo, 58-59. 
Compared to Isidore's very long genealogy of the descendants of Shem, ${ }^{81}$ the text in the middle column of the Pelagian scheme is very short. But this passage also basically follows the Etymologies:

\begin{tabular}{|c|c|}
\hline Madrid, BNE, 1513, fol. 1v & Isidore, Etymologiarum, 9.2.2-5, ed. Lindsay \\
\hline $\begin{array}{l}\text { "Sem. Aries. Arfaxar | Ouis. Ex sem gen- } \\
\text { tes | XXVII. Filii sem elam unde elamites. } \\
\text { Assurus | unde assurii; Arfaxarus | unde } \\
\text { aradii [sic!]; Aram unde | sirii. Arfaxarus } \\
\text { genuit eber | a quo ebrei« }\end{array}$ & $\begin{array}{l}\text { "Gentes autem a quibus divisa est terra, quin- } \\
\text { decim sunt de Iaphet, triginta et una de Cham, } \\
\text { viginti et septem de Sem, quae fiunt septua- } \\
\text { ginta tres, vel potius, ut ratio declarat, sep- } \\
\text { tuaginta duae; totidemque linguae, quae per } \\
\text { terras esse coeperunt, quaeque crescendo } \\
\text { provincias et insulas inpleverunt. Filii Sem } \\
\text { quinque singulariter gentes singulas procrea- } \\
\text { verunt. Quorum primus Elam, a quo Elamit- } \\
\text { ae principes Persidis: secundus Assur, a quo } \\
\text { Assyriorum pullulavit imperium: tertius Ar- } \\
\text { phaxat, a quo gens Chaldeorum exorta est: } \\
\text { quartus Ludi, a quo Lydii: quintus Aram, a } \\
\text { quo Syri, quorum metropolis fuit Damascus. } \\
\text { Filii Aram, nepotes Sem, quattuor: Hus et Ul } \\
\text { et Gether et Mes. Hus Traconitidis conditor, } \\
\text { qui inter Palaestinam et Coelesyriam tenuit } \\
\text { principatum, unde fuit Iob, secundum quod } \\
\text { scriptum est [Hiob 1, 1]: Vir erat in terra Hus: } \\
\text { secundus Ul, a quo Armenii: tertius Gether, a } \\
\text { quo Acarnanii sive Curiae: quartus Mes, a quo } \\
\text { sunt hi qui vocantur Maeones. Posteritas Ar- } \\
\text { phaxat filii Sem; Heber nepos Arphaxat, a quo } \\
\text { Hebraei; Iectam filius Heber, a quo Indorum } \\
\text { orta est gens; Sale filius Iectam, a quo Bactria- } \\
\text { ni, licet eos alii Scytharum exules suspicantur« }\end{array}$ \\
\hline
\end{tabular}

81 Already in Genesis 10, Shem has the longest list of descendants. Hieke, Völkertafel, 30. 
Shem. Aries. Arpachshad; Ovis. From Shem [descent] twenty seven peoples; the sons of Shem: Elam, from whom [descent] the Elamites; Ashur, from whom [descent] the Assyrians; Arpachshad, from whom [descent] the Arades [Arabs?]; Aram, from whom [descent] the Syrians; Arpachshad begat Eber, from whom [descent] the Hebrews. ${ }^{82}$
Now, of the nations into which the earth is divided, fifteen are from Japheth, thirty-one from Ham, and twenty seven from Shem, which adds up to seventy three - or rather, as a proper accounting shows, seventy two. And there are an equal number of languages, which arose across the lands and, as they increased, filled the provinces and islands. The five sons of Shem each brought forth individual nations. The first of these was Elam, from whom descended the Elamites, princes of the Persians. The second Asshur, from whom sprang the empire of the Assyrians. The third Arpachshad, from whom the nation of the Chaldeans arose. The fourth Lud, from whom came the Lydians. The fifth Aram, from whom descended the Syrians, whose capital city was Damascus. There are four sons of Aram, the grandsons of Shem: Uz, Hul, Gether, and Mash. Uz was the founder of Trachonitis - a principate between Palestine and Celesyria - from which came Job, as it is written (Job 1:1): >There was a man in the land of Uz. The second, Hul, from whom came the Armenians. The third, Gether, from whom came the Acarnanians or Curians. The fourth Mash, from whom descended those who are called Maeones. The posterity of Arpachshad the son of Shem follows. The grandson of Arpachshad was Heber (i.e. Eber), from whom descended the Hebrews. The son of Eber was Joktan, from whom the nation of the Indians arose. The son of Joktan was Sheleph, from whom came the Bactrians - although others suspect that these were Scythian exiles. ${ }^{83}$

82 Madrid, BNE, 1513, fol. 1v; see again de Toro Vial, Pelayo de Oviedo, 20.

83 Isidore of Seville, Etymologiarum, 9.2.2-5, ed. Lindsay; trans. Barney et al., Etymologies, 192. 
The same is true of the right-hand column, representing the descendants of Cham, populating Africa:

\begin{tabular}{|c|c|}
\hline Madrid, BNE, 1513, fol. 1v & Isidore, Etymologies, 9.2.10-14, ed. Lindsay \\
\hline $\begin{array}{l}\text { "Leena. Babil[onia/ones]. Nabu|cadonosor. } \\
\text { | Egiptus. Kam. | De Kam gentes | XXX | } \\
\text { Filii Kam: cus unde | ethiopes. Mesres } \\
\text { un|de egiptii. Futh unde | friges. Canaam } \\
\text { unde | cananei. Cus genuit sa|ba unde sabei. } \\
\text { Heui|lat unde getuli id est Mauri» }\end{array}$ & $\begin{array}{l}\text { »Filii Cham quattuor, ex quibus ortae sunt } \\
\text { gentes haec: Chus, a quo Aethiopes progeniti; } \\
\text { Mesraim, a quo Aegyptii perhibentur exorti. } \\
\text { Phut, a quo Libyi. Vnde et Mauretaniae flu- } \\
\text { vius usque in praesens Phut dicitur, omnis- } \\
\text { que circa eum regio Phuthensis. Chanaam, } \\
\text { a quo Afri et Phoenices et Chananaeorum } \\
\text { decem gentes. Item ex nepotibus Cham filii } \\
\text { Chus, nepotes Cham sex. Filii Chus: Saba et } \\
\text { Hevila, Sabatha, Rhegma, Seba, Cuza. Saba, a } \\
\text { quo progenili et appellati Sabaei, de quibus } \\
\text { Vergilius (Georg. 2, 117): Solis est thurea virga } \\
\text { Sabaeis. Hi sunt et Arabes« }\end{array}$ \\
\hline $\begin{array}{l}\text { Leena. Babylon. Nebuchadnezzar. Egyptus. } \\
\text { Cham. From Cham [descent] thirty [eigh- } \\
\text { ty] peoples. The sons of Cham: Chus, from } \\
\text { whom [descent] the Ethiopians; Mizraim, } \\
\text { from whom [descent] the Egyptians; Phut, } \\
\text { from whom [descent] the Phrygians; Cana- } \\
\text { an, from whom [descent] the Canaanites; } \\
\text { Chus begat Saba, from whom [descent] the } \\
\text { Sabaeans; Hevilat, from whom [descent] } \\
\text { the Getules, who are the Moors. }{ }^{84}\end{array}$ & $\begin{array}{l}\text { There were four sons of Ham, from whom } \\
\text { sprang the following nations. Cush, from } \\
\text { whom the Ethiopians were begotten. Mes- } \\
\text { raim (i.e. Egypt), from whom the Egyptians } \\
\text { are said to have risen. Put, from whom came } \\
\text { the Libyans - whence the river of Mauretania } \\
\text { is called Put still today, and the whole region } \\
\text { around it is called Puthensis. Finally Canaan, } \\
\text { from whom descended the Africans and the } \\
\text { Phoenicians and the ten tribes of Canaanites. } \\
\text { Again, the sons of Cush, grandsons of Ham - } \\
\text { the grandchildren of Ham were six. The sons } \\
\text { of Cush: Saba (i.e. Seba), Havilah, Sabtah, } \\
\text { Raamah, Seba, and Cuza. Saba, from whom } \\
\text { the Sabaeans were begotten and named, con- } \\
\text { cerning which Vergil (Geo. 2.117): The bough } \\
\text { of frankincense is the Sabaeans' alone. These } \\
\text { are also the Arabians. }{ }^{85}\end{array}$ \\
\hline
\end{tabular}

84 Madrid, BNE, 1513, fol. 1v. I, again, renounced geographic or topographic text in this area of the scheme; de Toro Vial, Pelayo de Oviedo, 20.

85 Isidore of Seville, Etymologiarum, 9.2.10-14, ed. Lindsay; trans. Barney et al., Etymologies, 193. 
As will be discussed below, some of the ethnonyms from this Isidorean genealogy play an important role in the depiction of Iberian history in the chronicles following the map, in the later parts of BNE 1513. Hence, this map contains a genealogy, correlating with ChristianIberian historical writing and its chronicler's identification of the cultural and religious "Other", the foreign rulers in the Iberian Peninsula. It connects representations of ethnicity with geographical imaginations. ${ }^{86}$

\section{The Scheme as a Diagram}

"A diagram is the commonest form of mapping. Everybody creates a map in diagrammatic style for one reason or another - ruthlessly selecting only the essential topographical detail and reducing direction to straight or boldly curved lines - if only to guide visitors to their destination. Not everyone, though, recognises that their scribbles are a form of mapping, or that the simple schematic figures they see in books are maps cleverly designed for a specific purpose - that of instant and unambiguous communication between individuals familiar with the subject under discussion. ${ }^{87}$ Following Catherine Delano-Smith's argument, the scheme from the Corpus Pelagianum can be seen as a paragon for a diagram, since it reduces geographical information to a minimum to achieve a trichotomy in the depiction of the world, thereby enabling the inclusion of a universal genealogy, leading from the Flood to the author's present. The depicted order is a result of generalisation. ${ }^{88}$ Hence, this scheme persuades the beholder of an even clearer order for the world, its history and its inhabitants than any textual description of the very same subject could. This is reasoned by its clear and almost simple appearance, while simultaneously offering complex meanings ${ }^{89}$ that can be realised through abstraction. ${ }^{90}$ Thus, a scheme like the one in BNE 1513 is a concept of knowledge transformation and conservation ${ }^{91}$ as well as a model of an imagined reality of the world. ${ }^{92}$ This model becomes established for the beholder through its pictoriality. ${ }^{93}$

86 Weeda, Ethnic identification and stereotypes, 591.

87 Delano-Smith, Maps as diagrams, 32.

88 Meynen, Flache Blicke, 49. Müller, Formen des Anfangs, 93-94 explains that to understand the world one had to abandon its manifest appearance in favour of geometry. Hieke, Völkertafel, 24 calls this »Bewältigung von Komplexität«, the overcoming of complexity, but refers to the genealogy in Genesis 10 itself, that is to the ethnic complexity rather than to the geographical, although it is equally applicable to both. Concerning the spatial order of knowledge in Isidore's Etymologies and their principle of simplification, see Merrills, Geography and memory, 61-62.

89 Haug et al., Diagramme im Gebrauch, 263; Tanneberger, Visualisierte Genealogie, 531: "Sichtbares ist tendenziell leichter zu vermitteln und eher glaubhaft zu machen. "Trans.: »Visible things tend to be easier to communicate and more believable.«

90 Meynen, Flache Blicke, 40, 42.

91 Haug et al., Diagramme im Gebrauch, 265.

92 Mahr and Wendler, Bilder zeigen Modelle, 191, 194.

93 Mahr and Wendler, Bilder zeigen Modelle, 200. 
The contours of BNE 1513, fol. $1 \mathrm{v}$ build the framework in which the text was positioned. Hence, two fields of knowledge interact in this scheme, spatial order and genealogy. ${ }^{94}$ Furthermore, the field of genealogy can be subdivided into identification and history, due to its character as a discipline that looks back into history to identify contemporaries. Consequently, at a first glance this geo-genealogical scheme seems very simple, but this reduction leads to a complex abstraction and combination of different fields of knowledge ${ }^{95}$ and is, thus, an impressive intellectual assessment that combines at least four ways of depicting knowledge.

\section{Strategies of Identification and the Interaction with Historical Writing}

Self-identification

Even though the Visigothic kingdom ceased to exist in 711 and its territory came under Arab rule during the first decades of the eighth century, Christian Iberian authors, especially those in Asturias, referred to themselves as Goths. ${ }^{96}$ Accordingly, the cartographer's "own " people in this geo-genealogical scheme are identified as the descendants of Japheth, since the gens gotorum is the final ethnonym in the northern, i. e. European line of ancestry. Furthermore, this ethnonym is positioned near the toponym Spania. From a certain point of view, one could argue that this gens gotorum is now presented as the spearhead of the Roman Empire, understood as the final age of the world, due to the position of this ethnonym near the illustration of this city. ${ }^{97}$ Therefore, the cartographer's own people in this scheme could even represent the focus of salvation history, although they are not located in the centre.

In addition to the imitation of Isidore's ninth book of the Etymologies, this Japhethan genealogy contains another Isidorean detail, which was overlooked or, at least, not further investigated by de Toro Vial, when he translated this geo-genealogical scheme.$^{98}$ Directly under the term Septentrio, the genealogy continues with the name "Magot«. It seems almost certain, that the biblical figure or people of Magog is meant here, yet the author of the scheme definitely wrote it with final »t« as »Magot« instead of the more usual final »g«, for »Magog«.

94 This kind of entanglement may be compared with the structure of textiles, being the basis of building an object. In our case the scheme's shape comprises a specific interaction of form and text, as well as textual array. Schneider, Diagramm und bildtextile Ordnung, 10-11.

95 Pinet, Task of the Cleric, 24.

96 The innumerable studies on this field cannot be listed here. In order not to extend the list of studies used for this article even more, I refer to already cited works, in which this subject has already been thematically addressed: Prelog, Chronik Alfons' III., 151 n. 84; Bronisch, Reconquista und Heiliger Krieg, 91, 125, 154.

97 See above, 197.

98 de Toro Vial, Pelayo de Oviedo, 20. 
This presumably deliberate misspelling triggers, or rather stresses, the reference to Isidore's identification of the Goths as descendants of Magog, due to the similar sound in the final syllable of the latter. ${ }^{99}$ Hence, the author's "own « people is traced back to a biblical origin. After Isidore and, furthermore, after the Arab conquest of the Iberian Peninsula, this identification of the Goths continues, as can be seen in examples form the ninth-century Asturian chronicles, ${ }^{100}$ or in this geo-genealogical scheme.

The historical connection drawn between the last Visigoths and the Asturian kingdom is, thus, also part of the redaction of the Chronicle of Alfonso III, which is also part of the manuscript BNE 1513. It refers to the fall of the Visigothic kingdom, the flight of the Goths into Frankish and Asturian regions, and the famous dialogue between the rebel Pelayo (not to be mixed up with Bishop Pelayo of Oviedo) and the collaborator Bishop Oppa before the depiction of the battle of Covadonga, in which Pelayo is confronted with the idea of restoring the (Visi)Gothic armies against the foreign rulers. ${ }^{101}$

\section{Identification of the Cultural and Religious "Other"}

The Chronicle of Alfonso III, including redaction C as it appears in BNE 1513, offers a variety of synonymous ethnonyms concerning the foreign rulers of the Iberian Peninsula. ${ }^{102}$ The foreign rulers are named Saracens $\aleph^{103}$, »Arabs $\aleph^{104}$, Ishmaelites $\aleph^{105}$, and $» C h a l d e a n s \aleph^{106}$. Additionally, the Calif of Damascus is once referred to as a "Babylonian king « ${ }^{107}$ None of these ethnonyms appears in the geo-genealogical scheme - at least not obviously. But in connection with Isidorean knowledge, it is possible to ascribe them to a specific son of Noah.

99 Isidore of Seville, Historia Gothorum, ed. Mommsen, 268: "Gothorum antiquissimam esse gentem [certum est]: quorum originem quidam de Magog Iafeth filio suspicantur a similitudine ultimae syllabae [...]«; Trans. Donini and Ford, History of the Kings, 3: "It is certain that the Goths are a very old nation. Some conjecture from the similarity of the last syllable that their origin comes from Magog, son of Japhet [...]«; Isidore of Seville, Etymologiarum, 9.2.89, ed. Lindsay: "Gothi a Magog filio Iaphet nominati putantur, de similitudine ultimae syllabae, quos veteres magis Getas quam Gothos vocaverunt; gens fortis et potentissima, corporum mole ardua, armorum genere terribilis. De quibus Lucanus $(2,54)$ : Hinc Dacus premat inde Getes occurrat Iberis«; trans. Barney et al., Etymologies, 197: "The Goths are thought to have been named after Magog, the son of Japheth, because of the similarity of the last syllable. The ancients called them Getae rather than Goths. They are a brave and most powerful people, tall and massive in body, terrifying for the kind of arms they use. Concerning them, Lucan (Civil War 2.54): Let here a Dacian press forward, there a Getan (Getes) rush at the Iberians."

100 Marschner, Depiction of the Saracen, 218-221 and 219 n. 11 for the identification of the Goths as Gog already undertaken by Ambrose, with a rather negative interpretation.

101 Madrid, BNE 1513, fols 43v, 45r; Redactio C, ed. Prelog, 76, 81.

102 Concerning the interpretation of these ethnonyms, their synonymous meaning, and the development of their use in Christian-Iberian historical writing see Marschner, Familiar stranger. Since the meaning of these denominations has been investigated in this article and, further on until the Christian-Iberian historical writing of the twelfth century, in another article, Marschner, Development of ethnic terminologies, I will not go into detail here and rather just name the different ethnonyms that appear. Furthermore, I will interpret them concerning their relation to the geo-genealogical scheme and only as far as necessary in relation to the further medieval Iberian identification discourse, since this is already the subject of the aforementioned articles.

103 For instance, Madrid, BNE 1513, fols 45r, 51r; Redactio C, ed. Prelog, 80, 85, 100, 103

104 For instance, Madrid, BNE 1513, fols 43v, 45r, 46r, 47v; Redactio C, ed. Prelog, 76, 81, 88.

105 For instance, Madrid, BNE 1513, fols 45r, 47v; Redactio C, ed. Prelog, 81, 88.

106 For instance, Madrid, BNE 1513, fols 45v-46r, 50r, 51r, 51v-52v; Redactio C, ed. Prelog, 82-83, 99, 102, 104-105, 107-108.

107 Madrid, BNE 1513, fol. 43v; Redactio C, ed. Prelog, 76. 
Looking in the book of Genesis, one becomes aware of further progenitors being thematised after the Table of Nations. Possibly the most famous of them is Abraham, who was a Hebrew and father of Ishmael. According to the geo-genealogical scheme, the Hebrews are descendants of Shem. Furthermore, the ethnonym Ishmaelites belongs to the descendants of Ishmael. Consequently, the Ishmaelites have to be identified as Shemitic people. Additionally, since in the Chronicle of Alfonso III »Ishmaelites «, "Saracens «, "Arabs«, and »Chaldeans" are different ethnonyms for one and the same people, the author of the chronicle perceived the foreign rulers as being descendants of Shem, no matter which of the above names was given to them at any time. Since in Isidorean and later Christian-Iberian tradition the term "Saracens" is linked to Abraham's wife Sara, ${ }^{108}$ there is again no doubt that they should also be defined as Shemites.

The denomination of the foreign rulers as Arabs either found its expression in the geogenealogical scheme through a misspelling or else cannot be linked to the illustration at all. In the lineage of Shem, we read that the "Aradii« are descended from Arpachshad. ${ }^{109}$ One could speculate that in "Aradii « "d « and "b « were mixed up, and also that an incorrect ending of the ethnonym occurred to the author. In that, admittedly unlikely, case, "Aradii« would be a strongly altered form of "Arabes « and, thus, the Arabs were part of Shem's offspring. On the other hand, Isidore actually mentions a people named "Aradii«, but they are given as descendants of Cham, not of Shem. ${ }^{110}$ The same holds true for the actual Arabs, as they are mentioned by Isidore. They appear in the lineage of Cham as sons of Saba and also have an alternative name, where they are called the "Sabeans « ${ }^{111}$ Therefore, the Arabs, who were identified as Ishmaelites and Saracens in the historiographical texts of BNE 1513, either appear in a heavily changed spelling, or the term "Aradii« is strikingly misplaced, or they are not mentioned at all and the "Aradii« should be identified as a completely different people.

108 Marschner, Depiction of the Saracen, 225. Isidore of Seville, Etymologiarum, 9.2.6, ed. Lindsay: "Ismael filius Abraham, a quo Ismaelitae, qui nunc corrupto nomine Saraceni, quasi a Sarra, et Agareni ab Agar.« Trans. Barney et al., Etymologies, 192: »son of Abraham was Ishmael, from whom arose the Ishmaelites, who are now called, with corruption of the name, Saracens, as if they descended from Sarah, and the Agarenes, from Agar (i.e Hagar)." See also Isidore of Seville, Etymologiarum, 9.2.57, ed. Lindsay: "Saraceni dicti, vel quia ex Sarra genitos se praedicent, vel sicut gentiles aiunt, quod ex origine Syrorum sint, quasi Syriginae. Hi peramplam habitant solitudinem. Ipsi sunt et Ismaelitae, ut liber Geneseos docet, quod sint ex Ismaele. Ipsi Cedar a filio Ismaelis. Ipsi Agareni ab Agar; qui, ut diximus, perverso nomine Saraceni vocantur, quia ex Sarra se genitos gloriantur." Trans. Barney et al., Etymologies, 195: "The Saracens are so called either because they claim to be descendants of Sarah or, as the pagans say, because they are of Syrian origin, as if the word were Syriginae. They live in a very large deserted region. They are also Ishmaelites, as the Book of Genesis teaches us, because they sprang from Ishmael. They are also named Kedar, from the son of Ishmael, and Agarines, from the name Agar (i.e. Hagar). As we have said, they are called Saracens from an alteration of their name, because they are proud to be descendants of Sarah."

109 See the second table above.

110 Isidore of Seville, Etymologiarum, 9.2.24, ed. Lindsay: »[...] Aradius, a quo Aradii sunt, qui Aradum insulam possiderunt angusto fretu a Phoenicis litore separatam. "Trans. Barney et al., Etymologies, 193: "Arvadah, from whom are the Arvadites, who occupied the island Aradum, separated by a narrow strait from the Phoenician coastline." The same genealogical origin is given to the "Aradii« and the Arabs, for instance, by Frechulf of Lisieux, Historiarum libri XII, 1.1.27, ed. Allen, 54-56, who also allocated the "Aradii« to a specific island: "Filii Cham: Chus et Mesraim, Futh et Chanaan [...] Interpreatur nunc Saba >Arabiar [...] Chanaan autem genuit [...] Sineum et Aradium [...] Aradii sunt qui Aradum insulam possederunt [...].« Trans.: »The sons of Cham: Chus and Mizraim, Phut and Canaan [...] now Saba is interpreted as >Arabiar [...] also Canaan begat [...] Sineus and Aradius [...] the Arades are the ones, who possessed the island of Aradum. «Yet, the "Aradii« as well as "Arabia « are linked to Cham in Frechulf's genealogical history.

111 See the third table above; Rotter, Abendland und Sarazenen, 79-80, 82. 
So far, I have not come across another genealogy in which either the Arabs or the "Aradii« were specifically identified as descendants of Shem. However, the synonymous use of the term "Arabs" and "Saracens" in the chronicles of BNE 1513 indirectly marks the Arabs as descendants of Shem rather than Cham. Thus, if the "Aradii" refer to the "Arabs", then the scheme and the historiographical texts of BNE 1513 coincide concerning this people's origin but run counter to Isidore's identification of them.

It is also remarkable that in Isidore's Etymologies Arpachshad's sons are the Chaldeans, ${ }^{112}$ which is a term often used as a denomination for the foreign rulers of the Iberian Peninsula in post-conquest Christian-Iberian chronicles, also those contained in BNE $1513,{ }^{113}$ but this ethnonym does not appear in the geo-genealogical scheme. Hence, an ethnonym that was frequently used in the historiographical texts of BNE 1513 and undoubtedly associated with Shem's lineage in Isidore's work, which seems to be the basis of most of the codex's content, was instead replaced in the geo-genealogical scheme with a name that cannot be clearly identified: »Aradii«. Even though Isidore's Etymologies were somewhat authoritative, in some cases they were altered - either to adapt Isidorean knowledge to someone's own contemporary circumstances or because they were mixed up with other sources and, thus, caused divergent depictions in later works dealing with the same topics.

An ethnonym which can be found in the geo-genealogical scheme appears in a passage of redaction $\mathrm{C}$ of the Chronicle of Alfonso III about the military leader Musa, who was of the "nacione Getulus" and whose clan was called "Benkazi« by the "Chaldeans «. ${ }^{114}$ If one relates this specific passage to the scheme, marking the rebelling Musa as "Getule" could be interpreted as a clear sign for identifying him as a member of a Chametan people, since the "Getules « in the map are the last descendants of Cham and are identical with the "Moors «. ${ }^{115}$ But, looking into the actual history of the Banu Qasi, as one has to translate "Benkazi«, and also into older versions of the Chronicle of Alfonso III from the ninth century, one is quickly proven wrong: the Banu Qasi were Goths who converted to Islam. ${ }^{116}$ Obviously, the later redaction of the Chronicle of Alfonso III offers an ethnonym for a member of the Banu Qasi that is different from their original denomination in the ninth-century versions of this chronicle. How could this be explained? With Isidore one could identify the Goths with the Getes ${ }^{117}$ and could assume a confusion of "Getes« and "Getules «, but this seems rather unlikely since the Getes were a people living on the western shore of the Black Sea ${ }^{118}$ and the Getules were

112 See the second table above.

113 See above n. 15 and 106.

114 Madrid, BNE 1513, fol. 51v; Redactio C, ed. Prelog, 104: „Muza quidem nomine, nacione Getulus, sed ritu mamenciano cum omni gentis sue [...] deceptus, quod Caldei vocitant Benkazi, contra Cordubensem regem rebellavit [...]. « Trans.: "A certain man by the name of Musa - a Getule by birth but deceived by the Muhammadan rite along with all of his family [...] which the Chaldeans call the Banu Qasi - rebelled against the Córdoban king [...].«

115 Madrid, BNE 1513, fol. 1v: "getuli id est Mauri«.

116 Chronica Adephonsi III, ed. Gil, 428: "Muzza quidam nomine, natione Gothus sed ritu Mamentiano, cum omni gentis sue deceptus, quos Caldei vocitant Benikazi, contra Cordubensem regem revellavit.« Trans. Wolf, Conquerors and Chroniclers, 142: "A certain man by the name of Musa - a Goth by birth but deceived by the Muhammadan rite along with all of his family, which the Chaldeans call the Banu Qasi - rebelled against the Córdoban king [...].«

117 See the above quotation of the Etymologies in n. 99.

118 Haarmann, Lexikon der untergegangenen Völker, 116.

medieval worlds • No. $13 \cdot 2021 \cdot 195-228$ 
definitely identified with the North African Moors. Additionally, the text of the Chronicle of Alfonso III, as it appears in BNE 1513, mentions the Goths several times with an unmistakable spelling. Therefore, it is hard to attribute the identification as Goth only with a different term to this characterisation of Musa. Accordingly, this singular choice of ethnic terminology in the text - if not a mistake by the copyist - does not seem to fit with the geo-genealogical scheme, which distinguishes the Goths clearly from the Getules, just like the historiographical texts in the very same codex do. Another option was the wilful changing of the ethnonyms by the author of redaction $\mathrm{C}$ of the Chronicle of Alfonso III, who maybe could not explain to himself the atypical name "Musa» for a "Goth« and, thus, turned this member of the Banu Qasi and his entire clan into »Getules«.

With the Chronicle of Sampiro following directly the text of the Chronicle of Alfonso III in BNE $1513,{ }^{119}$ further ethnonyms can be added to the terminological repertoire of this codex. Next to "Saracens «, a frequently appearing denomination for the foreign rulers of the Iberian Peninsula is "Hagarenes $" .{ }^{120}$ Since Hagar, after whom the "Hagarenes " were named, was the mother of Ishmael, whom she had with Abraham, the "Hagarenes « are descendants of Shem, too. ${ }^{121}$ Even though this seems very simple, the Chronicle of Sampiro offers a very confusing passage. In Christian-Iberian historical writing, eighth to ninth centuries, we find a clear distinction between the "Arabs" (who were also identified as "Saracens", "Ishmaelites", "Hagarenes", and "Chaldeans") and the "Berbers" (who were identified as the "Getules" or "Moors « and generally the inhabitants of northern Africa). ${ }^{122}$ With a single appearance of the ethnonym "Moors « in the Pelagian redaction of the Chronicle of Sampiro addressed here, this distinct imagination of the "Other " began to blur. Describing the battle of Simancas in $939 \mathrm{AD}$, Sampiro reports 80,000 dead Moors in the hostile army, which had come from Córdoba and was led by a Saracen or Hagarene »king«, the military leader Abu Yahya. ${ }^{123}$ I have

119 Madrid, BNE 1513, fol. 52v. The Chronicle of Sampiro begins with an initial »A« in red ink, yet this does not mark the start of a new text. Instead, the same type of coloured initial capital letters occurs repeatedly throughout the manuscript, signalling new paragraphs. Hence, this element in the mise-en-page signals continuity of the text rather than the beginning of a new one. As mentioned above, the Chronicle of Sampiro can be understood as a continuation of the Chronicle of Alfonso III.

120 Madrid, BNE 1513, fols 54r, 59r, 61r-v, 62v; Sampiro of Astorga, Chronica, ed. Pérez de Urbel, 283, 312, 313, 326, $330,331,336$, each on the left column. Concerning »Hagarenes« being a synonym for "Saracens«, "Ishmaelites«, "Arabs", and "Chaldeans" in the Christian-Iberian tradition, see Marschner, Depiction of the Saracen, 230-232.

121 See the above quotation in $\mathrm{n} .108$.

122 Marschner, Development of ethnic terminologies.

123 Madrid, BNE 1513, fols 6ov-61r; Sampiro of Astorga, Chronica, ed. Pérez de Urbel, 325-326, left column: »Rex quidem sarracenorum nomine Aboiahia regi magno Ranimiro colla submisit, et omnem terram dicioni regis nostri subiugauit. Abderrechman regi suo Cordubense mentitus est, et regi catholico cum omnibus suis se tradidit [...] Postea Abderrechman, rex Cordubensis, cum magno exercitu Septimancas properauit [...] Rex noster catholicus hec audiens, illuc ire disposuit cum magno exercitu. Et ibidem dimicantibus ad inuicem, dedit Dominus uictoriam regi catholico qualiter die II $^{a}$ feria inminente festo sanctorum Justi et Pastoris deleta sunt ex eis LXXXa milia maurorum. Etiam et ipse Aboiahia rex agarenorum ibidem a nostris comprehensus est [...].« Trans.: »Indeed, Abu Yahya, the king of the Saracens bowed to the power of Ramiro the Great and subjugated the entire territory under the rule of our king. He betrayed his Córdoban king, Abd al-Rahmān and [therefore] together with all of his men delivered himself to the Catholic king. [...] When our Catholic king heard this, he arranged to head there with a big army. And there, they encountered in battle and the Lord gave victory to the Catholic king while 80,000 of the Moors were killed during the two days of the feasts of Justinus as Pastor. And Abu Yahya himself, the king of the Hagarenes, has been arrested by ours in that very place." 
explored elsewhere the possibility of a multi-ethnic army, as well as the fact that this is the only appearance of the ethnonym "Moors" in the Chronicle of Sampiro. The interpretation of this term in this passage of the chronicle is not as easy as it seems and leaves too many questions unanswered to take up a position. In the depiction of the battle of Simancas, the term seems to be synonymous with the other ethnonyms. On the other hand, this chronicle is based on the historiographical tradition, in which the term was usually distinguished from the "Arabs" and their alternative denominations. ${ }^{124}$ Taken alongside the geo-genealogical considerations of BNE 1513, fol. 1v, it is surely better to simply distinguish two groups as being mentioned within this passage and assign the "Moors" to the lineage of Cham. Nevertheless, this would raise the question of why only "Moors « would have died or at least why the chronicler counted only the fallen "Moors « and not the "Saracens" or "Hagarenes" too, who very likely also died in such a battle?

However, we also have to keep in mind that this codex contains the oldest surviving manuscript of the Chronicle of Sampiro. Thus, the content of an eleventh-century chronicle reappears in a twelfth- or thirteenth-century codex and, therefore, was not safe from alteration, perhaps even by Bishop Pelayo himself. ${ }^{125}$ Furthermore, political changes in the Muslim realms in the Iberian Peninsula affected the Christian's perception of the foreign rulers between the eleventh and twelfth centuries with the Almoravids taking over in the middle of the eleventh century a north African dynasty that clearly would be identified with the "Moors". They then ruled over a region that had formerly been under Saracen power. ${ }^{126}$ From a Christian-Iberian chronicler's perspective, this could cause a mixing of ethnonyms. ${ }^{127}$ Therefore, there is a possibility that in this case "Moors" was a synonym for "Saracens", "Hagarenes«, etc., especially in a text that was copied and presumably altered in twelfthcentury Oviedo.

Finally, "Almoravids" is also the term that can be added to the spectrum of denominations for the foreign rulers in the series of chronicles contained in BNE 1513, as it appears once in the Chronicon regum Legionensium. ${ }^{128}$ Even though this term does not appear in the geo-genealogical scheme, it is obvious that the Almoravids should have been perceived as being descendants of Cham due to their (north) African origin. Nevertheless, Pelayo of Oviedo identified the Almoravids with the Saracens and Hagarenes and, in doing so, as descendants of Shem. ${ }^{129}$ The way Pelayo handled the term "Almoravids « and the fact that the oldest version of the Chronicle of Sampiro appears in the Corpus Pelagianum, strengthen

124 Marschner, Development of ethnic terminologies.

125 Bronisch, Reconquista und Heiliger Krieg, 160.

126 Singer, Almoraviden, 449; Oliver Pérez, Sarraceno, 120-121.

127 In most of twelfth-century Christian-Iberian historical writing ethnic denominations for the »Other « very likely depended on where they came from, al-Andalus or beyond the Mediterranean, Africa. Bru, Posar un nom, 130, 133; Sirantoine, What's in a word?, 231-238; Di Branco and Wolf, Berbers and Arabs, 4-5.

128 Madrid, BNE 1513, fol. 68r; Chronicon regum Legionensium, ed. Fernández Conde, 35: »Post hec etiam, tantis prospertiatibus, ad tantam elacionem peruenit, ut extraneas gentes que Almorabites uocantur ex Affrica [sic!] in Spania per regen [sic!] Abenabet misit, cum quibus prelia multa fecit et multa contumelia, dum uixit, accepit ab eis." Trans. Barton and Fletcher, World of el Cid, 85: "After this, he reached a pitch of elation because of such good fortune that at the instigation of King Abenabet some foreigners called Almoravids were summoned from Africa to Spain, with whom he fought many battles, and whilst he lived he suffered many attacks by them."

129 Marschner, Biblical elements and the »Other«, 81. 
the assumption of a synonymous comprehension of »Moors « and »Saracens" (plus the other synonymous ethnonyms) in this version of the Chronicle of Sampiro. The explanation for the different depiction of the Moors in the geo-genealogical scheme and the historiographical texts still eludes us.

According to all the above, the historiographical texts in BNE 1513 differ repeatedly from the genealogical knowledge as presented in the geo-genealogical scheme. In the very same codex, the information given is partially inconsistent and, thus, confusing. How might this be explained? Of course, one could always argue that a compiler simply wanted to collect texts without pondering their contents in every detail. Hence, discrepancies like ethnic identification were accepted, or maybe not even noticed. Then again, we could take into account what such a scheme, such a diagram is good for - to reduce the complexity of the world surrounding us. The complicated situation of a foreign group ruling over the realms of another different people, plus the many synonymous ethnonyms, each with a different meaning, and the etymological derivations of their names resulted in a very complex situation for an Iberian Christian dealing with history.

Furthermore, the simple character of the geo-genealogical scheme offers the possibility of filling it with appropriate information as necessary, depending on the needs of a chronicler dealing with foreigners that he has to depict somehow. ${ }^{130}$ BNE 1513 , fol. $1 \mathrm{v}$ offers precisely this potential. If we, again, compare the genealogical information in BNE 1513 with that given in Isidore's Etymologies, we can create two simple lineages for each:

As follows from the above, in the Etymologies Shem is the progenitor of the Chaldeans, the Hebrews, Abraham, Hagar and the Hagarenes, and Ishmael and the Ishmaelites; Cham is the progenitor of the Egyptians, the Moors and the Sabeans, who are Arabs.

By comparison, in BNE 1513 Shem is the progenitor of the "Aradii« - whoever they might represent in this case -, the Hebrews and, in conclusion, of Abraham, Hagar, and Ishmael; whereas Cham is the progenitor of the Egyptians and the Getules, who are Moors.

No definitive solution can be presented for the problem of the "Aradii« based on the current state of evidence, but the above-mentioned confusing equation of the Moors and the Almoravids with the other ethnonyms could become a little bit more plausible if we add but one component besides the changing political situation: Hagar may be a key figure. The bondwoman of Abraham, with whom he fathered Ishmael, was Egyptian. ${ }^{131}$ Thus, with Hagar belonging to the Chametan tribe and Abraham being of Semitic origin, their son Ishmael is technically both and so are his descendants. Finally, according to the final text in BNE 1513, Bishop Pelayo's History of the four cities, it was the "sons of Hagar" who invaded Hispania. ${ }^{132}$ Nowadays we know it was an Arab-Berber conquest. ${ }^{133}$ From our current point

130 Hieke, Völkertafel, 36.

131 Genesis 16, 1: »igitur Sarai uxor Abram non genuerat liberos sed habens ancillam aegyptiam nomine Agar.« Trans.: "Now Sarai, the wife of Abram, had brought forth no children: but having a handmaid, an Egyptian, named Agar."

132 Madrid, BNE 1513, fol. 115v; Pelayo of Oviedo, De fundatione, ed. Martínez, 125: „Et ab introitu filiorum Agar in Yaspania usque hodie quod est Era Ma C.L.XXX sunt anni CCCC." Trans.: "And from the invasion of the sons of Hagar in Hispania until today, the era 1180, are 400 years." The Spanish Era is an alternative calendar, always adding 38 years to the actual $\mathrm{AD}$.

133 By way of example, see Bronisch, Reconquista und Heiliger Krieg, 1 n. 2; Di Branco and Wolf, Berbers and Arabs, 3-4. 
of view, bearing in mind the probable key role of Hagar, with Pelayo's choice of allocation, all the subtle distinctions in medieval ethnic terminology and identification of ChristianIberian historiography have simply been consolidated. Denominating all groups of foreign rulers of the Iberian Peninsula, appearing in post-conquest historical writing, as "sons of Hagar" consequently leads to the identification of the Moors as Saracens (and Arabs and Chaldeans etc.) and vice versa.

\section{Conclusion}

Medieval strategies of identification were complex and occasionally difficult. Even though simplifications like Pelayo's denomination of the eighth-century conquerors of the Iberian Peninsula as "sons of Hagar « or the geo-genealogical scheme of BNE 1513 can be interpreted as attempts to create a clear picture, these attempts often failed since there have always been competing opinions on the identification of peoples. This is comprehensible in two ways: in one and the same codex different strategies of identification can be found and are only rarely explained; but also, long-lasting discourses on the identification of peoples come to the fore, if one compares textual identifications of peoples throughout several centuries, as was done here from Isidore to Pelayo.

In terms of the peoples appearing in Iberian history, the interaction of the geo-genealogical scheme and the historiographical texts in BNE 1513 is diverse. The identifications of peoples in the scheme can be seen as an addition to the knowledge given in the chronicles of the codex and the other way around. Furthermore, the scheme presents the relationship, or rather distinction, between the Goths, who were understood as the cartographer's own people, and the foreign rulers over major parts of the former Visigothic kingdom. The interactions of the cultural and religious "Other" and the successors of the (Visi)Goths that are depicted in the historiographical texts of BNE 1513 are supplemented by the depiction of the historical protagonists' origins in the geo-genealogical scheme. But the relationship between this graphic depiction and the chronicles in this codex also includes inconsistencies, like the ambivalence concerning the Getules, partially the Moors, the Arabs and their origins as well as the "Aradii«. Even though this geo-genealogical scheme depicts the world and its inhabitants in a very individual manner and, thus, differs strongly in some essential points from other comparable medieval illustrations like world maps, it cannot remove these discrepancies.

Identification is always constructed and depends on contemporary political circumstances. ${ }^{134}$ What these reasons for identification were is often far from clear, and can be rather complex. This complexity could also appear in one and the same codex, as the comparison of the geo-genealogical scheme in BNE 1513 with its historiographical content has shown, no matter how much a diagram like the aforementioned scheme tried to reduce this complexity. Hence, it is not only the actual identity of peoples - whatever it may be ${ }^{135}-$ that was (and is) complicated. The construction of identities that were meant to make complex realities more comprehensible were also rarely as straightforward as we might expect.

134 Fried, Schleier der Erinnerung, 270; Coulmas, Ich, wir und die Anderen, 89.

135 Coulmas, Ich, wir und die Anderen, 64-65.

medieval worlds $\bullet$ No. $13 \cdot 2021 \cdot 195-228$ 


\section{Acknowledgements}

I am grateful for the opportunity to present early versions of this research in two webinars in summer 2020. The first was the "Frühjahrsklausur" of the Vienna Doctoral Academy "Medieval Academy", moderated by Matthias Meyer (University of Vienna). The second was the "Scriptures in Transition" webinar, moderated by Helmut Reimitz (Princeton University). In both events I benefited from the participants' discussions and comments after my presentations. Furthermore, I would like to thank Christoph Mauntel (University of Tübingen) for his valuable hints in our correspondence about this topic. Many thanks go to Thom Gobbitt (Austrian Academy of Sciences, Institute for Medieval Research (IMAFO), Vienna) for his codicological and palaeographical expertise, as well as polishing the language of this text. This article is also a result of a fruitful discussion with Salvatore Liccardo (IMAFO). Additionally, Marcus Richter (Leibniz Institute for Applied Geophysics, Hannover) kindly commented on this work as a geographer. 


\title{
References
}

\author{
Abbreviations \\ BNE = Biblioteca Nacional de España \\ ÖNB = Österreichische Nationalbibliothek
}

\section{Manuscripts}

Madrid, BNE, 1358

Madrid, BNE, 1513

Madrid, BNE, 2805

Madrid, BNE, Vitrina 14-2, fols 12v, 62v-63r.

Vienna, ÖNB, Cod. 67, fol. 117v.

Alonso Álvarez, Raquel, El obispo Pelayo de Oviedo (1101-1153): Historiador y promotor de códices iluminados, Semata: Ciencias Sociais e Humanidades 22 (2010) 331-350.

Alonso Álvarez, Raquel, El Corpus Pelagianum y el Liber Testamentorum ecclesiae Ouetensis: Las "reliquias del pasado" de la cathedral de Oviedo y su uso propagandístico en la obra del Obispo Pelayo de Oviedo (1101-1153), in: Marie-Françoise Alamichel and Robert Braid (eds.), Texte et Contexte: Littérature et Histoire de l'Europe médiévale, Actes du Colloque, Université Paris-Est Marne-la-Vallée, 23-24 octobre 2009 (Paris, 2011) 519-548.

Alonso Álvarez, Raquel, El rey Alfonso VI (m. 1109) en la obra del obispo Pelayo de Oviedo (m. 1153), in: Etelvina Fernández González (ed.), Imágenes del poder en la Edad Media: Estudios in Memoriam del Prof. Dr. Fernando Galván Freile 2 (León, 2011) 15-34.

Alonso Álvarez, Raquel, La obra histórica del obispo Pelayo de Oviedo (1089-1153) y su relación con la Historia legionensis (llamada silensis), in: Georges Martin (ed.), Historia legionensis (llamada silensis): Écriture de l'histoire, Historiographie léonaise, castillane et navarraise de XIIe siècle 3, L'Historia (dite) Silensis, e-Spania: Revue interdisciplinaire d'études hispaniques médiévales et modernes (14 December 2012). Retrieved on 11 November 2020: journals.openedition.org/e-spania/21586.

Barton, Simon and Richard Fletcher, The World of el Cid: Chronicles of the Spanish Reconquest, Manchester Medieval Sources (Manchester, 2000).

Baumgärtner, Ingrid, Die Wahrnehmung Jerusalems auf mittelalterlichen Weltkarten, in: Dieter Richard Bauer, Klaus Herbers and Nikolas Jaspert (eds.), Jerusalem im Hoch- und Spätmittelalter: Konflikte und Konfliktbewältigung - Vorstellungen und Vergegenwärtigungen, Campus historische Studien 29 (Frankfurt/Main, 2001) 271-334.

Baumgärtner, Ingrid, Die Welt im kartographischen Blick: Zur Veränderbarkeit mittelalterlicher Weltkarten am Beispiel der Beatustradition vom 10. bis 13. Jahrhundert, in: Wilfried Ehbrecht, Angelika Lampen, Franz-Joseph Post and Mechthild Siekmann (eds.), Der weite Blick des Historikers: Einsichten in Kultur-, Landes- und Stadtgeschichte, Peter Johanek zum 65. Geburtstag (Cologne, 2002) 527-549.

von den Brincken, Anna-Dorothee, Die Ausbildung konventioneller Zeichen und Farbgebungen in der Universalkartographie des Mittelalters, Archiv für Diplomatik 16 (1970) 325-349.

von den Brincken, Anna-Dorothee, Mappa mundi und Chronographia: Studien zur imago mundi des abendländischen Mittelalters, Deutsches Archiv für Erforschung des Mittelalters 24 (1968) 118-186. 
von den Brincken, Anna-Dorothee, Mundus figura rotunda, in: Anton Legner (ed.), Ornamenta Ecclesiae: Kunst und Künstler der Romanik, Katalog zur Ausstellung des Schütgen-Museums in der Josef-Haubrich-Kunsthalle 1 (Cologne, 1985) 99-106.

Bronisch, Alexander Pierre, Reconquista und Heiliger Krieg: Die Deutung des Krieges im christlichen Spanien von den Westgoten bis ins frühe 12. Jahrhundert, Spanische Forschungen der Görresgesellschaft 2/35 (Münster, 1998).

Bru, Meritxell, Posar un nom: Els almoràvits com a moabites a finals del segle XI, Faventia 31/1-2 (2009) 129-149.

Casariego [Fernández-Noriega], Jesús Evaristo, Crónicas de los Reinos de Asturias y León, Biblioteca universitaria Everest (León, 1985).

Chronica Adephonsi III, ed. Juan Gil [Fernández], Chronica Hispana saeculi VIII et IX: Cura et studio, Corpus Christianorum Continuatio Medievalis 65 (Turnhout, 2018) 383-433. English translation: Kenneth Baxter Wolf, Conquerors and Chroniclers of Early Medieval Spain, Translated Texts for Historians 9 (Liverpool, 2011) 129-143.

Coulmas, Florian, Ich, wir und die Anderen: Das Zeitalter der Identität (Zürich, 2020).

Delano-Smith, Catherina, Maps as diagrams, in: Peter Barber (ed.), The Map Book (London, 2005) 32-33.

Destombes, Marcel, Mappemondes: A.D. 1200-1500, Catalogue préparé par la Commission des Cartes Anciennes de l'Union Géographique Internationale, Imago mundi, A Review of Early Cartography, Supplement 4, Monumenta Cartographica Vetustoris Aevi 1 (Amsterdam, 1964).

Di Branco, Marco and Kordula Wolf, Berbers and Arabs in the Maghreb and Europe, medieval era, in: Immanuel Ness (ed.), The Encyclopedia of Global Human Migration (New York, 2013) 1-8.

Díaz [Martínez], Pablo de la Cruz, El mito godo en la construcción de Castilla, in: Pablo de la Cruz Díaz [Martínez], Fernando Luis Corral and Iñaki Martín Viso (eds.), El historiador y la sociedad: Homenaje al Profesor José Ma. Mínguez, Estudios históricos \& geográficos 152 (Salamanca, 2013) 53-65.

Edson, Evelyn and Emilie Savage-Smith, Medieval Views of the Cosmos (Oxford, 2004).

Edson, Evelyn, Emilie Savage-Smith and Anna-Dorothee von den Brincken, Der mittelalterliche Kosmos: Karten der christlichen und islamischen Welt (Darmstadt, 2005).

Fernández Conde, Francisco Javier, Pelayo de Oviedo: Edición Crítica de la Chronica y su Pensamiento Político, Estudios Históricos la Olmeda, Colección Piedras Angulares (Gijón, 2020).

Fletcher, Richard, The Episcopate in the Kingdom of León in the Twelfth Century, Oxford historical monographs (Oxford, 1978).

Frechulf of Lisieux, Historiarum libri XII, ed. Michael Idomir Allen, Frechulfi Lexoviensis episcopi opera omnia, Cura et studio, Textus, Corpus Christianorum Continuatio Mediaevalis 169 A (Turnhout, 2002) 17-724.

Fried, Johannes, Der Schleier der Erinnerung: Grundzüge einer historischen Memorik (Munich, 2004).

Galván Freile, Fernando, El ms. 1513 de la Biblioteca Nacional de Madrid: Primeros pasos en la miniatura gótica hispana, Anuario de Estudios Medievales 27 (1997) 479-497.

Galván Freile, Fernando, Iconografía, ornamentación y valor simbólico de la imagen: El Códice Albeldense, in: Etelvina Fernández González (ed.), Imágenes del poder en la Edad Media: Estudios in Memoriam del Prof. Dr. Fernando Galván Freile 1 (León, 2011) 225-294. 
Gautier-Dalché, Patrick, L'Héritage antique de la cartographie médiévale: Les problèmes et les acquis, in: Richard John Alexander Talbert and Richard W. Unger (eds.), Cartography in Antiquity and the Middle Ages: Fresh Perspectives, New Methods, Technology and Change in History 10 (Leiden, 2008) 29-66.

Gil [Fernández], Juan, Chronica Hispana saeculi VIII et IX: Cura et studio, Corpus Christianorum Continuatio Medievalis 65 (Turnhout, 2018).

Goetz, Hans-Werner, Gott und die Welt: Religiöse Vorstellungen des frühen und hohen Mittelalters 1/2/II, Die materielle Schöpfung: Kosmos und Welt III, Die Welt als Heilsgeschehen, Orbis mediaevalis, Vorstellungswelten des Mittelalters 13/2 (Berlin, 2012).

Haarmann, Harald, Lexikon der untergegangenen Völker: Von Akkader bis Zimbern, Beck'sche Reihe 1643 (Munich, 2012).

Harley, John Brian, Maps, knowledge, and power, in: Denis Cosgrove and Stephen Daniels (eds.), The Iconography of Landscape: Essays on the Symbolic Representation, Design and Use of Past Environments, Cambridge Studies in Historical Geography 9 (Cambridge, 1989) 277-312.

Harvey, Paul Dean Adshead, Mappa mundi: The Hereford World Map (London, 1996).

Haug, Henrike, Christina Lechtermann and Anja Rathmann-Lutz, Diagramme im Gebrauch, Das Mittelalter: Perspektiven mediävistischer Forschung, Zeitschrift des Mediävistenverbandes 22/2 (2017) 259-266.

Hieke, Thomas, Die Völkertafel von Genesis 10 als genealogische Raumordnung: Form, Funktion, Geographie, in: Almut-Barbara Renger and Isabel Toral-Niehoff (eds.), Genealogie und Migrationsmythen im antiken Mittelmeerraum und auf der Arabischen Halbinsel, Berlin Studies of the Ancient World 29 (Berlin, 2014) 23-40.

Hieke, Thomas, Genealogy, in: Samuel E. Balentine (ed.), The Oxford Encyclopedia of the Bible and Theology 1, Oxford Encyclopedias of the Bible (Oxford, 2015) 391-396.

Inventario general de manuscritos de la Biblioteca Nacional 4 (1101 a 1598) (Madrid, 1958).

Inventario general de manuscritos de la Biblioteca Nacional 8 (2475 a 2824) (Madrid, 1965).

Isidore of Seville, Etymologiarum sive originum libri XX, ed. Wallace Martin Lindsay, Isidori Hispalensis episcopi etymologiarum sive originum libri XX 1, Scriptorum Classicorum Bibliotheca Oxoniensis (Oxford, 1911). English translation: Stephen A. Barney, W. J. Lewis, Jennifer A. Beach and Oliver Berghof, The Etymologies of Isidore of Seville (Cambridge, 2006) 39-406.

Isidore of Seville, Historia Gothorum, Wandalorum, Sueborum ad a. DCXXIV, ed. Theodor Mommsen, Chronica Minora saec. IV. V. VI. VII 2, Monumenta Germaniae Historica, Auctores Antiquissimi 11/2 (Berlin, 1894) 268-295. English translation: Guido Donini and Gordon B. Ford, Jr., Isidore of Seville's History of the Kings of the Goths, Vandals, and Suevi (Leiden, 1966) 3-43.

Jerez, Enrique, Arte compilatoria pelagiana: La formación del Liber cronicorum, in: Amaia Arizaleta (ed.), Poétique et chronique: L'écriture des textes historiographiques au Moyen Âge (péninsule Ibérique et France), Méridiennes: Série Études médiévales ibériques (Toulouse, 2008) 47-87.

Julian of Toledo, Historia Wambae regis, ed. Wilhelm Levison, in: Jocelyn Nigel Hillgarth (ed.), Sancti Iuliani Toletanae sedi episcopi opera 1, Corpus Christianorum Series Latina 115/1 (Turnhout, 1976) 218-255.

Krusch, Bruno, Fredegarii et aliorum chronica: Vitae sanctorum, Monumenta Germaniae Historica, Scriptores rerum Merovingicarum 2 (Hanover, 1888). 
Mahr, Berndt and Reinhard Wendler, Bilder zeigen Modelle - Modelle zeigen Bilder, in: Gottfried Boehm, Sebastian Egenhofer and Christian Spies (eds.), Zeigen: Die Rhetorik des Sichtbaren, Eikones (Munich, 2010) 182-204.

Marschner, Patrick Sebastian, Biblical elements and the "Other" in the Chronicon regum Legionensium, Medieval Worlds 8 (2018) 66-85.

Marschner, Patrick Sebastian, The depiction of the Saracen foreign rule in the Prophetic Chronicle through biblical knowledge, Journal of Transcultural Medieval Studies 5/2 (2018) 215-239.

Marschner, Patrick Sebastian, The development of ethnic terminologies for the foreign rulers in Christian-Iberian chronicles, eighth to twelfth centuries, in: Walter Pohl and Cinzia Grifoni (eds.), Ethnic Terminologies in Eurasian Perspective (Leiden, forthcoming).

Marschner, Patrick Sebastian, The familiar stranger: Biblical perception and depiction of Muslims in Christian chronicles of the Iberian Peninsula, c. 900, in: Hans-Werner Goetz and Ian Nicholas Wood (eds.), Otherness in the Middle Ages, International Medieval Research, Selected Proceedings of the International Medieval Congress (Leeds) 25 (Turnhout, forthcoming).

Mauntel, Christoph, Klaus Oschema, Jean-Charles Ducène and Martin Hofmann, Mapping continents, inhabited quarters and the four seas: Divisions of the world and the ordering of spaces in Latin-Christian, Arabic-Islamic and Chinese cartography in the twelfth to sixteenth centuries. A critical survey and analysis, Journal of Transcultural Medieval Studies 5/2 (2018) 295-367.

Merrills, Andy, Geography and memory in Isidore's Etymologies, in: Keith D. Lilley (ed.), Mapping Medieval Geographies, Geographical Encounters in the Latin West and Beyond, 3001600 (Cambridge, 2013) 45-64.

Meynen, Gloria, Flache Blicke, Off topic 1 (2009) 38-51.

Miller, Konrad, Mappae mundi: Die ältesten Weltkarten 1, Die Weltkarte des Beatus (776 n. Chr.) (Stuttgart, 1895).

Müller, Kathrin, Formen des Anfangs: Sphärendiagramme aus dem 13. Jahrhundert, in: Birgit Schneider (ed.), Diagramme und bildtextile Ordnungen, Bildwelten des Wissens, Kunsthistorisches Jahrbuch für Bildkritik 3/1, (Berlin, 2005) 85-96.

Müller, Kathrin, Visuelle Weltaneignung: Astronomische und kosmologische Diagramme in Handschriften des Mittelalters, Historische Semantik 11 (Göttingen, 2008).

Oliver Pérez, Dolores, Sarraceno: Su Etymología e Historia, Al-quantara: Revista de estudios árabes 15/1 (1994) 99-130.

Payne, Stanley George, Visigoths and Asturians reinterpreted: The Spanish grand narrative restored?, in: Ivy A. Corfis and Ray Harris-Northall (eds.), Medieval Iberia: Changing Societies and Cultures in Contact and Transition, Colección Támesis A, Monografías 247 (Woodbridge, 2007) 47-56.

Pelayo of Oviedo, Chronicon regum Legionensium, ed. Francisco Javier Fernández Conde, Pelayo de Oviedo: Edición Crítica de la Chronica y su Pensamiento Político, Estudios Históricos la Olmeda, Colección Piedras Angulares (Gijón 2020) 28-37. English translation: Simon Barton and Richard Fletcher, The World of el Cid: Chronicles of the Spanish Reconquest, Manchester Medieval Series (Manchester, 2000) 74-89.

Pelayo of Oviedo, De fundatione quarundam civitatum, ed. Marcos G. Martínez, La »Historia de cuarto ciudades« de Don Pelayo, obispo de Oviedo, Boletín del Instituto de Estudios Asturianos 102 (1981) 121-126. 
Pérez de Urbel, Justo, Sampiro: Su crónica y la monarquía leonesa en el siglo x, Escuela de Estudios Medievales, Estudios 26 (Madrid, 1952).

Pinet, Simone, The Task of the Cleric: Cartography, Translation, and Economics in ThirteenthCentury Iberia (Toronto, 2016).

Podossinov, Alexander V., Die Orientierung der alten Karten von den ältesten Zeiten bis zum frühen Mittelalter, Cartographica Helvetica: Fachzeitschrift für Kartengeschichte 7 (1993) 33-43.

Prelog, Jan, Die Chronik Alfons' III: Untersuchungen und kritische Edition der vier Redaktionen, Europäische Hochschulschriften 3, Geschichte und ihre Hilfswissenschaften 134 (Frankfurt am Main/Bern/Cirencester, 1980).

Redactio C a Pelagio episcopo Ovetensi conscripta, ed. Jan Prelog, Die Chronik Alfons' III: Untersuchungen und kritische Edition der vier Redaktionen, Europäische Hochschulschriften 3, Geschichte und ihre Hilfswissenschaften 134 (Frankfurt/Main, 1980) 69-108.

Rotter, Ekkehart, Abendland und Sarazenen: Das okzidentale Araberbild und seine Entstehung im Frühmittelalter, Studien zur Sprache, Geschichte und Kultur des islamischen Orients, Beihefte zur Zeitschrift »Der Islam« 11 (Berlin, 1986).

Sampiro of Astorga, Chronica, ed. Justo Pérez de Urbel, Sampiro: Su crónica y la monarquía leonesa en el siglo x, Escuela de Estudios Medievales, Estudios 26 (Madrid, 1952) 273-434.

Sánchez Alonso, Benito, Crónica del obispo Don Pelayo: Textos Latinos de la Edad Media Española, Volúmenes publicados, Sección Primera: Crónicas 3 (Madrid, 1924).

Schneider, Birgit, Diagramm und bildtextile Ordnung, in: Birgit Schneider (ed.), Diagramme und bildtextile Ordnungen, Bildwelten des Wissens, Kunsthistorisches Jahrbuch für Bildkritik 3/1, (Berlin, 2005) 9-19.

Simek, Rudolf, Erde und Kosmos im Mittelalter: Das Weltbild vor Kolumbus (Munich, 1992).

Singer, Hans-Rudolf, Almoraviden, Lexikon des Mittelalters 1 (Stuttgart, 1999) 449-450.

Sirantoine, Hélène, What's in a word? Naming "Muslims" in medieval Christian Iberia, in: Chris Jones, Conor Kostick and Klaus Oschema (eds.), Making the Medieval Relevant: How Medieval Studies Contribute to Improving our Understanding of the Present, Das Mittelalter, Perspektiven mediävistischer Forschung, Beihefte 6 (Berlin 2020) 225-238.

Tanneberger, Tobias, Visualisierte Genealogie - Zur Wirkmächtigkeit und Plausibilität genealogischer Argumentation, in: Gerhard Wolf and Norbert H. Ott (eds.), Handbuch Chroniken des Mittelalters (Berlin, 2016) 521-540.

de Toro Vial, José Miguel, Pelayo de Oviedo y su compilación histórico-geográfica: El Corpus Pelagianum del manuscrito 1513 de la Biblioteca Nacional de España, Autoctonía. Revista de Ciencias Sociales e Historia 4/1 (2020) 1-28.

Van Duzer, Chet, A neglected type of medieval Mappamundi and its re-imaging in the Mare Historiarum (BNF MS lat. 4915, fol. 26v), Viator 43/2 (2012) 277-302.

Vulgate = Biblia Sacra iuxta vulgatam versionem, ed. Robert Weber and Roger Gryson (5th revised edition) (Stuttgart, 2007), English translation: Douay-Rheims Bible. Accessed on 21 April 2021: www.biblestudytools.com/rhe/.

Weeda, Claire, Ethnic identification and stereotypes in western Europe, circa 1100-1300, History Compass 12/7 (2014) 586-606.

Witt, Werner, Lexikon der Kartographie, Kartographie und ihre Randgebiete, Enzyklopädie B (Vienna, 1979).

Wolf, Beat, Jerusalem und Rom: Mitte, Nabel - Zentrum, Haupt. Die Metaphern »Umbiculus mundi" und "Caput mundi" in den Weltbildern der Antike und des Abendlands bis in die Zeit der Ebstorfer Weltkarte (Bern, 2010). 
Wolf, Kenneth Baxter, Conquerors and Chroniclers of Early Medieval Spain, Translated Texts for Historians 9 (Liverpool, 2011).

Woodward, David, Medieval Mappaemundi, in: John Brian Harley and David Woodward (eds.), The History of Cartography 1, Cartography in Prehistoric, Ancient, and Medieval Europe and the Mediterranean (Chicago, 1987) 286-370.

\section{List of Figures}

Figure 1: Geo-genealogical scheme. Madrid, BNE, 1513, fol. 1v. Accessed on 12 November 2020: bdh-rd.bne.es/viewer.vm?id=0000005990\&page $=8$.

Figure 2: T-O map and V-in- $\square$ map in a copy of Isidore's Etymologies. Wien, Österreichische Nationalbibliothek, Cod. 67, fol. 117v. Accessed on 12 November 2020: digital.onb.ac.at/ RepViewer/viewer.faces?doc=DTL_5059920\&order=246\&view=SINGLE.

Figure 3: V-in- $\square$ map in a copy of Beatus of Liébana's Commentary on the Apocalypse. Madrid, BNE, Vitr. 14-2, fol. 12v. Accessed on 12 November 2020: bdh-rd.bne.es/viewer. vm?id=0000051522\&page $=24$.

Figure 4 (a-b): World map in a copy of Beatus of Liébana's Commentary on the Apocalypse. Madrid, BNE, Vitr. 14-2, fols 62v-63r. Accessed on 12 November 2020: bdh-rd.bne.es/viewer.vm?id=0000051522\&page $=127$ and bdh-rd.bne.es/viewer. vm?id=0000051522\&page $=128$ (merged by the author). 